\title{
SEC NO-ACTION LETTERS: INFORMAL ADVICE AS A DISCRETIONARY ADMINISTRATIVE CLEARANCE
}

\author{
WILLTAM J. LOCKHART*
}

The Securities and Exchange Commission has long encouraged its.staff to provide to the public written advice about the need to comply, or means of complying, with the registration obligations of the 1933 Securities Act. ${ }^{1}$ Typically, that advice is provided in the form of so-called "no-action letters," in which the staff advises a stockholder, upon inquiry, whether it would recommend Commission enforcement action if he should sell his stock, without prior registration, under the circumstances and in the manner proposed by the stockholder. The term is used loosely here to refer to all staff responses determining "no-action" requests-denial as well as approval of no-action positions.

Though neither statute nor regulation imposes an obligation to render no-action advice, ${ }^{2}$ the no-action process has become a major staff function, particularly. in the Division of Corporation Finance, which processes most of the no-action letters issued by the SEC staff.

The no-action process is performed primarily by informal written exchanges between staff and applicant, results in determinations based upon staff-developed interpretations and policies as well as upon discretionary consideration of the applicant's circumstances, and significantly affects the financial condition of applicants with little or no opportunity for agency or judicial review. For these reasons, in' searching for wisdom about informal and discretionary functions of federal agencies, the Informal Action Committee of the Administrative Conference of the United States made an extensive investigation of the no-action process as administered in the Division of Corporation Finance of the SEC. This article examining those discretionary processes is drawn largely from the author's report as a consultant to the Informal Action Committee. ${ }^{3}$

\footnotetext{
- Professor of Law, University of Utah.

${ }^{2}$ I5 U.S.C. §77; 3 Loss, Securities Regulatton 1894-99 (2d ed. I96i); Commission on Organization of the Executtve Branch of the Government, Task Force Report on Legal Services AND Procedure I89 (I955).

- Regulations merely inform applicants of the availability of the advisory process and the manner in which requests for advice should be submitted. I7 C.F.R. $\$ \S 200.8 \mathrm{x}, 202 . \mathrm{\text {(d) }}$, 202.2 (Supp. x97I); SEC Securities Act Release No. 5r27 (Jan. 25, r97I) CCH FED. SEC. L. REP. I 66,48I.Io (describing procedure and form for no-action requests).

${ }^{B}$ Administrative Conference of the United States, Report of the Committee on Informal Action in Support of Recommendation No. 19 ("SEC No-Action Letters Under Section 4 of the Securities Act of x933"), by William J. Lockhart, consultant, in I ADMINISTRATtVE CONFERENCE of THE UNITED STATES, Recommendations aND RepoRts 440 (January 8, I968-June 30, I970). [Hereinafter cited as Report.]

For a study of the no-action process based on currently available, published copies of no-action requests and responses and reaffirming most recommendations of the Report, see Lowenfels, SEC No-Action Letters: Some Problems and Suggested Approaches, 71 CoLum. L. REv. 1256 (I97I).
} 
The staff of the Division of Corporation' Finance in 1968 reported that it generated n'o-action letters at a rate of approximately 5000 per year, constituting approsimately eighty per cent of all no-action letters generated by the entire SEC staff. ${ }^{4}$ The objective of about four-fifths of the no-action letters rendered by the Office of Chief Counsel of the Division is to advise stockholders who have received unregistered stock whether they must register it before selling or risk SEC enforcement action. Both oral and written advice on that problem are given by the Chief Counsel's office. Oral advice tends to be general and interpretive; it assists counsel in identifying specific problems, often with a view to a more specific application for a no-action letter. Written advice in most cases is specific and conclusory; it includes little or no interpretive material but expresses the staff's conclusion whether, on a particular set of facts, it would recommend that the Commission take action if a stockholder should sell stock without registration.

The assurance provided by a no-action letter is treated as binding by the Commission, though the estoppel effect of such a letter has not been judicially determined. Such an assurance may also tend to discourage private lawsuits based on sales made without registration. However, because the no-action letter is founded upon carefully constructed factual representations, it is not regarded by enforcement personnel as a bar to investigations of unregistered sales until it is determined that the sale in question conformed to the factual representations.

\section{I}

\section{The Substantive Context}

This study of the no-action process in the Division of Corporation Finance (the "Division") was completed before the recent adoption of Rule $144 .^{\circ}$ The Commission

\footnotetext{
- Staff Memorandum to Wanner W. Gardner, in Report, app. E.

3 L. Loss, Securittes Reguldtion $1843-44$ (2d ed. I96r). But see United States v. Anzelmo, 319 F. Supp. II06, IIr7 (E.D. La. 1970).

SEC Securities Act Release No. 5098 (Oct. 29, 1970), [1970-197I Transfer Binder] CCH FED. SEc. L. REP. I 77,92I, announcing a policy of public availability of no-action letters cautioned that "[i]t should be recognized that no-action and interpretative responses by the staff are subject to reconsideration and should not be regarded as precedents binding on the Commission."

The collateral effect of a no-action letter occasionally has an impact upon litigation: e.g., in determining the obligations of a transfer agent to record shares in the name of the acquiring stockholder. See, e.g., Donlon Ventures, Inc. v. Avien, Inc., 158 N.Y.L.J., No. 5, p. 10, [1966-67 Decisions Transfer Binder] CCH FED. SEC. L. REP. I $9 \mathrm{I}, 96 \mathrm{I}$ ( 1967 ). And in a recent case the defendant's disregard of a staff letter declining to take a no-action position may have played a role in determining the willfulness of his violation, according to a staff attorney in the Division of Trading and Markets. See Inited States v. Wolfson, 269 F. Supp. 62I (S.D.N.Y. 1967), affd 405 F.2d 779 (2d Cir. 1968), cert. denied, 394 U.S. 946 (I969); United States v. Wolfson, 282 F. Supp. 772 (S.D.N.Y. r967), rev'd \& rem'd, 437 F.2d 862 (2d Cir. 1970).

'Rule ${ }^{2} 44$ was proposed as alternative to the recommendations of the Disclosure Study, note I4 infra, in SEC Securities Act Release No. 5087 (Sept. 22, 1970), [1970-197x Transfer Binder] CCH FED. SEc. L. REP. I 77,909. A revised proposal was published in SEC Securities Act Release No. 5 I86 CCH :Special Report, No. 387, Extra ed., Sept. 15, I971 (Sept. Io, r97r); and the Rule was adopted after 'further revisions in SEC Securities Act Release No. 5223 (Jan. Ir, r972), [1971-1972 Transfer Binder] .CCH FED. SEc. L. REP. I 78,487, effective April 15, I972. [Hereinafter cited as Relcase 5223.] The IRule provides an exemption from "underwriter" status (see discussion in text at notes I2-3I infra) for
} 
hopes, by that rule, to provide objective standards that will resolve many of the substantive uncertainties that prompted no-action requests and to reduce the burden of the no-action process. ${ }^{7}$ Despite adoption of that rule, however, an understanding of the substantive context which prompted the demand for no-action letters-as well as the adoption of Rule 144 -is essential to an understanding of the informal exercise of discretion in the no-action process. Further, that understanding may be necessary to understand the likelihood of continued demand for interpretive letters to clarify the application of Rule $144 .^{8}$

The substantive problems resolved by the no-action process in the Division prior to Rule I44 were basically concerned with two aspects of the single question of whether the 1933 Act ${ }^{9}$ requires that an applicant's stock be registered before sale: (I) whether the registration provisions are applicable to the applicant's proposed sale of stock, and (2) whether the applicant is relieved of the registration obligations by various exemptions created by statute and rule.

The basic purpose of the 1933 Act is to assure that public distributions of securities are accompanied by disclosure of all information material to a prospective stockholder's investment decision. The disclosure objectives are accomplished through the registration and prospectus delivery requirements of section 5 of that Act, which apply to any "sale" or "offer to sell" of a "security."10 Failure to comply with those

sales of unregistered stock by control persons and others who acquired their stock from the issuer, provided sales are made under preseribed terms and conditions.

${ }^{7}$ SEC Securities Act Release No. 5223 (Jan. II, I972) CCH FED. SEC. L. REP. $\{78,487$ supra note 6 , announcing adoption of Rule $I_{44}$ and analyzing the new rule, states at r2:

"The staff will not issue no-action letters with respect to resales of securities acquired after the effective date of the rule, but would issue interpretative letters to assist persons in complying with the new rule. In connection with securities acquired prior to the adoption of the rule, the staff would continue to issue no-action letters."

It is not clear whether the above withdraws the explicit invitation to broker-dealers to seek staff advice respecting the applicability of the 1933 and 1934 Acts to the sale of particular blocks of securities, as set forth in SEC Securities Act Release No. 5168 (July 7, 1971) CCH FED. SEC. L. REP. I 22,760.

${ }^{8}$ Examples of potential problems which may be resolved by interpretive letters include:

(I) the definition of "affiliate," which turns on a control relationship with the issuer, and leaves the concept of "control" undefined. It further leaves unclear whether the "issuer," with which the "affliate" shares a control relationship, refers to that term as it is defined in section 2 (II) of the I933 Act, thus including a second level of control-that is, affiliates of persons in a control relationship with the issuing company.

(2) the "brokers' transactions" by which sales are permitted under Rule I44. These are defined to require that the broker not be aware "of circumstances indicating that the person for whose account the securities are sold is an underwriter with respect to the securities." SEC Securities Act Release No. 5223, at II (Jan. II, 1972). That definition seemingly reincarnates the mystique of "a view to distribution" which the rule is designed to avoid. The impression is furthered by the following comment in the explanatory portion of SEC Securities Act Release, at 13:

"In view of the objectives and policies underlying the Act, the rule shall not be available to any individual or entity with respect to any transaction which, although in technical compliance with the rule, is part of a plan by such individual or entity to distribute or redistribute securities to the public. In such case, registration is required."

${ }^{\circ}$ Securities Act of 1933 , I5 U.S.C. $\$ 772-77 a a$ (1970).

${ }^{10}$ Rule I44, however, is based, in part, on the view that adequate public information is available without registration where the issuer has, for at least 90 days, been in compliance with the reporting requirements of the 1934 Act or has otherwise made certain specified information publicly available. 
requirements may subject the seller to the Commission's injunctive remedies under section 20 of the Act, the absolute liability to purchasers provided by section $\mathrm{I} 2(\mathrm{I})$, and possible criminal remedies under section 24 . In addition to those sanctions, a broker-dealer who participates in a sale of unregistered securities is subject to a range of sanctions including censure and denial, suspension, or revocation of his broker-dealer registration. ${ }^{11}$

In order to exempt regular trading transactions by persons not involved in promoting the sale of a security, persons other than an "issuer, underwriter or dealer" are exempted by section 4(r) of the Act from the registration and prospectus requirements of section 5. A further exemption, also to protect ordinary trading transactions, is given to dealers or brokers, provided they are not participating in a general public distribution of the issuer's stock. ${ }^{12}$. Because a liberal application of these exemptions would defeat the disclosure objectives of the Act, the Commission and staff have sought to limit their availability.

A primary means by which the Act reaches general public distributions of securities is by excluding an "inderwriter" from the section 4 exemption and by broadly defining that term. Thus, one who falls within the statutory definition of "underwriter" must comply with the registration and prospectus requirements of the Act. "Underwriter" is defined, in' section 2(II) of the r933 Act, as

any person who has purchased from an issuer with a view to, or offers or sells for - an issuer in connection with, the distribution of any security, or participates or has a direct or indirect participation in any such undertaking, or participates or has a participation in the direct or indirect underwriting of any such undertaking; but such term shall not include a person whose interest is limited to a commission - from: an underwriter or dealer not in excess of the usual and customary dis- tributors' or sellers' commission. As used in this paragraph the term "issuer" shall include, in addition to an issuer, any person directly or indirectly controlling or controlled by the issuer, or any person under direct or indirect common control with the issuer. ${ }^{13}$

The interpretation and application of the "underwriter" definition is the interpretive problem presented by the bulk of the requests for no-action letters received by the Division. And the interpretive problem most frequently encountered concerns the application of the phrase "with a view to ... distribution," which is generally acknowledged to import an extremely subjective test of "underwriter" status. Thus, the recent Disclosure Study conducted by the SEC staff under direction of former Commissioner Wheat, after analyzing the disclosure policies effected by the the 1933 Act, commented:

- [T] to a wholly subjective test by which to determine when a person is an "underwriter." Does the person who buys from the issuer or controlling stockholder

\footnotetext{
${ }^{11}$ Securities Exchange Act of 1934 , I5 U.S.C. $\$ \$ 780(b)(5) \&(7)$ (197r).

${ }^{12}$ Securities Act of 1933,15 U.S.C. $\$ \$ 77$ (d) (3) \& (4) (I97x).

${ }^{13}$ Securities Act of 1933 , I5 U.S.C. $\$ 77 b$ (Ir) (I97r).
} 
have the "view" or "intent" of later reselling his securities to the public? How can his true "intention" be accurately determined? ${ }^{14}$

Although the Disclosure Study condemns the subjective quality of these tests and their accompanying uncertainty, it is clear that the main dimensions of the interpretive positions taken by the staff are supported by judicial interpretations of the sections in question. ${ }^{15}$

The following paragraphs illustrate some of the typical interpretive problems to which the I933 Act, prior to the recent adoption of Rule I44, gave rise and particularly the magnitude of the uncertainties which generated no-áction requests. ${ }^{16}$ Much of the "law" reflected here has been displaced or modified by Rule $\mathrm{r}_{44}$ but is an essential background to the operation' of that rule and to the exercise of discretion in the no-action decision-making process.

(I) X Company issues a noncontrolling block of its stock to $A$; a director and controlling shareholder, relying on the exemption from registration provided by section 4(2) of the I933 Act for private sales that do not involve a "public offering." $A$ holds the stock for six months and now seeks to sell it through, a broker in the over-the-counter market. If $A$ sells, the staff will ordinarily conclude that he earlier purchased the security from his company (the "issuer") "with a view to . . . distribution" of the security, or that he is "selling for" the issuer "in connection with" a distribution. Under either construction, $A$ would be regarded as an "underwriter" who must comply with the registration requirements before selling his stock. ${ }^{17}$

The original sale by $\mathrm{X}$ Company to $A$ may also be subject to challenge on the ground that $A$ 's conduct demonstrates that his purchase contemplated a "public offering," thus compromising the original claim of a private offering exemption. The determinative question-one of "fact" in the staff's view-is whether $A$ 's intent, at the time he took the stock, was to hold for investment or to distribute the stock. Even though $A$, at the issuer's insistence, may have executed a letter reciting his "investment intent" at the time he took the stock, the staff may conclude that the latter sale is a more reliable indication of $A$ 's earlier state of mind. Hence, the staff would deny a request for a no-action letter. ${ }^{18}$

\footnotetext{
16 U.S. Securities \& Exchange Comm. Disclosure to Investors-A Reappraisal of Federaz AdominIstrattue Policies under tTE ' 33 and ' 34 ACTs 163 ( 1969 ). [Hereinafter cited as Disclosure Study.]

${ }^{15}$ See generally, J. Jennings \& H. Marsh, Securities Regulation 27I-363 (2d ed. I968).

${ }^{18}$ For a more detailed description of the interpretive uncertainties that arise from the subjective tests traditionally applied, see Disclosure STUDy I64-77.

${ }^{27}$ SEC Securities Act Release No. 4445 (Feb. 2, I962) CCH FED. SEC. L. REP. I 3090.10I; 4845.835; 22,753-759 [may be found in U.S. Securities \& Exchange Comm., Compilation of Releases Dealing WITH M,ATTERS FReQUENTLY ARISING UNDER THE SECURITIES ACT of 1933-44 (I965)] [hereinafter cited as Release 4445]; SEC Securities Act Release No. 4552 (Nov. 6, I962) CCH FED. SEC. L. REP. If 2770-83; 47,34r.I4 (Compilation, stipra at 49) [hereinafter cited as Release 4552]; SEC v. North Am. Research \& Dev. Corp., 280 F. Supp. 106, I2I-22 (S.D.N.Y. 1968), aff'd, 424 F.2d 63 (2d Cir. 1970); In re Ira Haupt \& Co., 23 S.E.C. 589, 596-99 (1946): But see example (5), infra, under former Rule 154.

${ }^{18}$ Release 4552.
} 
Finally, $A$ 's control relationship, though suggesting a motive to distribute on behalf of his company, is not essential to the above-described application of the Act. Thus, a noncontrolling shareholder who acquired a noncontrolling block of shares in similar circumstances may also be viewed as having acquired the shares with the forbidden intent or "view to ... distribution"; and a large number of no-action letters present just such circumstances. ${ }^{19}$

(2) $A$, in the above example, makes a further "private offering" of a noncontrolling block of $\mathrm{X}$ Company stock to a friend, $B$, who owns no other shares in X Company. $B$ buys the stock with a representation of his investment intent, holds the stock for six months and then seeks to sell through a broker in the overthe-counter market. Section 2(II) provides (only for purposes of that definition of "underwriter") that an "issuer" includes one in a "control" relationship with the issuer. Hence, $A$, a controlling shareholder of $\mathrm{X}$ Company, is an issuer and $B$ may be an underwriter if he bought from $A$ "with a view to ... distribution" rather than investment." ${ }^{20}$ Again, the deteminative "fact" is B's state of mind at the time of his purchase from $A$. If he should request a no-action letter, the staff would conclude that his sale after holding only six months demonstrates that he did not have sufficient investment intent at the time of his purchase. ${ }^{21}$ But if $B$ suffers a severe financial setback that was not foreseeable at the time of purchase, that "change of circumstances" may support the inference that he bought for investment, despite his present desire to sell. ${ }^{22}$

(3) In example ( $\mathrm{r}$ ), a broker who executes a sale of $A$ 's stock will want to determine whether $A$ is a so-called "controlling person" of $\mathrm{X}$ Corporation, and hence an issuer under the underwriter definition. If $A$ is a controlling person, then the broker will be "selling for" an issuer and, under the definition, will be an underwriter. ${ }^{23}$ The staff considers the question of control to be one of "fact," which must be determined by an analysis of all the circumstances and relationships between the person in question and the company and other controlling persons. ${ }^{24}$

(4) In examples (I) and (2), a broker who executes sales of stock for $A$ or $B$ will want to know whether either is an underwriter: whether $B$ took from $A$ "with a view to ... distribution," or whether $A$ took from the issuer with such intent. If that is the case, then, under section 2(II) of the I933 Act, the broker may also

\footnotetext{
${ }^{10}$ Id. See also Release 4445; Disclosure STUDy I6r-62.

${ }^{20}$ Disclostre Study I6I-62; SEC v. North Am. Research \& Dev. Corp., 280 F. Supp. 106, r21-22 (S.D.N.Y. I968), affd, 424 F.2d 63 (2d Cir. r97o); Israels, Checklist For Broker-Dealer Inquiry As To Customer's Control or Underwriter Relationship; Or Where Sale of Securities Proposed In Brokcrage Transaction In Reliance Upon S.E.C. Rule 154, x8 Bus. LAw. 94 (1962).

${ }^{21}$ Re: The Crowell-Collier Publishing Co. SEC Securities Act Release No. 3825 (Aug. 12, 1957) CCH FED. SEC. L. REP. If 2165.15; 2850.25; 2850.81 (Compilation, sttpra note 17, at I3); Release 4552; Practicing Law Insttrute, Transcrupt of PLI Forom on SEC Problems of Controlline StockHOLDERS AND IN UNDERWRITINGS 27-3I, 6I-62 (C. Israels ed. 1962).

${ }^{22}$ Release 4552.

${ }^{23}$ Release 4445; SEC Securities Act Release No. 5168 (July 7, 1971) CCH FED. SEc. L. REP. \22, 760 [hereinafter cited as Release 5168]; PLI Forum, supra note 21, at 51 .

si See 2 L. Loss, Securities REgulation 770-83 (2d ed. I96I).
} 
be an underwriter if he "participates or has a direct or indirect participation in" a sale by one who is a statutory underwriter. To avoid a charge (under section I5 (b) (5) (D) or (E) of the I934 Act) of willful violation of the Act and the accompanying possibility of disciplinary action, ${ }^{25}$ he should conscientiously investigate any facts which suggest that his seller occupies such an underwriter status. ${ }^{26}$

(5) In all examples, it is possible that the seller or broker might also want to determine whether the proposed sale constitutes a "distribution" of the X Company stock. Section $2(x)$ of the 1933 Act, in defining "underwriter," imposes that status only where there is a "view to ... distribution" or where a transaction is consummated "in connection with ... the distribution" of a security. The term "distribution" has always been regarded by the Commission "as essentially synonymous with public offering." 27

In defining the narrow exemption provided by section 4(4) of the I933 Act for "brokers' transactions" on behalf of controlling persons, the Commission, by rule, defined a "distribution" to exclude "transactions involving an amount not substantial in relation to the number of shares or units of the security outstanding and the aggregate volume of trading in such security." The rule permits brokers' sales (for controlling persons) within certain quantitative limitations by excluding such sales from the definition of the term "distribution"; but that use of the term is applicable only for purposes of the exemption for brokers' transactions. ${ }^{28}$ Thus, the broad statutory concept of "distribution," embracing any public sale, would be applicable to the term as it is used in the "underwriter" definition. And sales by a controlling person of stock privately acquired from the issuer, unless otherwise exempt, would involve a distribution, rendering both the seller and the broker statutory underwriters.

(6) Although one who sells for an issuing company or for a person controlling the issuer ordinarily falls within the statutory definition of underwriter, he may claim exemption under section 4(2) of the 1933 Act, which exempts "transactions by an issuer not involving any public offering." Under SEC v. Ralston Purina $\mathrm{Co}_{\text {, }}{ }^{29}$ the fundamental test that determines availability of the exemption is whether the offeror's relationship to the offerees in the private transaction is such that the latter "need ... the protections afforded by registration."30 But like the other interpretive problems described above, the question whether a transaction involves a public offering is viewed as "essentially a question of fact." And that fact question "necessitates a consideration of all surrounding circumstances, including such

\footnotetext{
${ }^{25}$ I5 U.S.C. $\$ \$ 780(\mathrm{~b})(5)$ (D) or (E) (1970).

${ }^{20}$ Release 4445; Release 5168; SEC v. North Am. Research \& Dev. Corp., 280 F. Supp. I06, 126-27 (S.D.N.Y. 1968), aff'd 424 F.2d 63 (2d Cir. 1970).

${ }^{27}$ Disclosure Study I6I-62.

${ }^{28}$ SEC Rule I54, I7 C.F.R. 230.154 (1972); SEC Securities Act Release No. 4818 (Jan. 21, I966) CCH FED. SEC. L. REP. I 2920. Rule 154 is rescinded by the Release announcing adoption of Rule 144 . SEC Securities Act Release No. 5223 (Jan. II, I972) CCH' FED. SEC. L. REP. \$78,478.

${ }^{20} 346$ U.S. II9 (1952).

${ }^{80} \mathrm{Id}$. at 127 .
} 
factors as the relationship between the offerees and the issuer, the nature, scope, size; type and manner of the offering."31

\section{The Demand for No-Action Letrers}

No ready thesis adequately explains the heavy demand for no-action letters reflected in the volume of letters generated by the Division. ${ }^{32}$ Applicants have not been surveyed to determine the motivations which prompted their requests, but inquiry and hypothesis suggest some probable answers.

A partial explanation; of course, lies in the complications, costs, and delays incident to registration of stock for sale, which may be avoided if it is determined that registration is not required. Yet very nearly $40 \%$ of the requests appear to be from nonlawyer stockholders ${ }^{33}$ who, presumably, would not be fully aware of the burdens of registration. And while the remaining $60 \%$ of the requests originate with counsel, the reasons for that demand are also not readily apparent. Certainly the determinations of "ultimate fact" involved in deciding whether registration is required are not unlike similar determinations typically made by counsel without agency assistance in advising clients about proposed transactions. Moreover, noaction letters are sought in the face of some substantial reasons for not doing so. Staff responses to no-action requests are frequently unfavorable-forty per cent so in one analysis ${ }^{34}$-and are particularly apt to be negative where the availability of an exemption from registration is for any reason doubtful..$^{35}$ Since the proposed transaction might easily have escaped regulatory attention if consumated without approval, and in view of the modest rate of success, it is apparent that other considerations prompt the large number of requests. Furthermore, though the usual delay in staff response to no-action requests is not excessive, ${ }^{36}$ the delay is undoubtedly substantial from the viewpoint of applicants anxious to take advantage of a favorable market opportunity.

Although potential sellers of securities have good reason not to seek no-action

\footnotetext{
${ }^{31}$ Release 4552; see SEC Securities Act Release No. 5121 (Dec. 30, 1970) CCH FED. SEc. L. REP. I77,943.

${ }^{32}$ See text at note 4 supra.

${ }^{83}$ This data derives from an examination by the author of no-action requests for the months of March and July, 1969 , on file in the SEC Division of Corporation Finance.

34 This rough datum derives from an examination by the author of responses to no-action requests for the periods Feb. I4-28, 1969 , and April r-x8, 1969, a total of $35 \mathrm{r}$ letters, on file in the SEC Division of Corporation Finance.

35 " $[\mathrm{T}]$ he big practical limitation upon the utility of 'no-action' requests is the difficulty of getting a reply from the Commission. The sad truth seems to be that you get 'no-action' letters in the clear cases but have an awful time getting them-or don't even ask-in the cases where you really need them." PLI Forum, supra note 2I, at I9 (comments of Mr. Gilroy).

${ }^{86}$ See text following note 57, infra. Israels, in his Checklist for Assuring Broker-Dealers' Compliance with Restrictions on the Sale of Unregistered Sectrities, comments that the no-action procedure is "cime-consuming." H. Wander \& W. Grienenberger (eds.), Serected ARticles ON Federal Secumuties LAw 79 (A.B.A. Section of Corporation, Banking and Business Law, I968).
} 
letters, the continuing stream of applications, may be explained by a combination of factors. 'These include ( $I$ ) issuers' fears of civil liability to ultimate purchasers of unregistered securities under section I2(I) of the I933 Act; (2) broker-dealers' fears of disciplinary proceedings brought against them on account of sales of unregistered securities; (3) the enforcement practices of the Commission and staff; and (4) the unreliability of counsel's advice as an assurance against disciplinary proceedings.

Technically, the absolute liability imposed by section I2( $I)$ of the r933 Act on anyone who, without registration, "offers or sells a security" would not appear to pose a threat to the issuing company as a result of a private placement, for the violation emanates from a further sale by the recipient. On further consideration, however, several very real threats to the issuer arise: (I) The Commission may commence a formal investigation, suspend trading or bring injunctive proceedings, with serious consequences in the securities market. (2) The ultimate purchaser may claim extensive civil liabilities on the theory that the sale was made to him as part of a distribution on behalf of the issuer-a claim that is encouraged by the statutory definition' of an underwriter as including one who "sells for" the issuer. (3) The practical financial consequence is enhanced by the prospect that the issuer may be required to show the potential liability on its balance sheet as a contingent claim. (4) Though it is more doubtful, it is possible that the original recipient of the private placement, if held liable to a later purchaser, would be able, in turn, to recover against the issuer because of the absolute liability imposed by section I2(I). For all of these reasons, it has been traditional for the issuer in a private sale to require an investment commitment from the purchaser to protect against a later sale which may destroy the private offering exemption-an eventuality made more likely by judicial and administrative construction. To assure that investment commitment, issuing companies are commonly advised to stamp an investment restriction on the face of the stock certificates issued in a private placement and to issue "stop transfer" orders to the tran'sfer agent, requiring notice to company counsel if the restricted shares should be presented for transfer to a later purchaser. ${ }^{37}$

Similar threats of liability and disciplinary proceedings confront a broker-dealer who executes a sale found to have been made without exemption and thus in violation of registration and prospectus requirements. Division personnel uniformly agree that a large proportion of no-action requests actually originate with broker-dealers. Even before the 1964 amendments to the I933 Securities Act, the Commission's exercise of its power over registration of broker-dealers had impressed upon them

\footnotetext{
${ }^{37}$ The Division of Corporation Finance has recently advised that it "will regard the presence or absence of an appropriate legend and stop-transfer instructions as a factor in considering whether the circumstances surrounding the offering are consistent with the exemption under Section $4(2)$ of the Act." SEC Securities Act Release No. 512I (Dec. 30, 1970). See Israels, Some Commercial Overtones of Private Placement, in $\mathrm{H}$. WANDER, stipra note 36 , at 125 , 129-30, $135-43$; Wood, The Investment-Intent Dilemma in Secondary Transactions, id. at $145,169-70$.
} 
their vulnerability to sanctions for participating in distributions of securities acquired through private placements. ${ }^{38}$ In a 1962 release, the Commission indicated that dealers would be held personally responsible for investigating the underlying facts supporting stockholders' claims of exemption, and that they are obliged "to make an appropriate investigation as to who their seller was and not simply to rely upon the opinion of the seller's attorney that no control relationship existed."30 And in a I97I release the Commission "reaffirmed" the broker-dealers' obligation to know their customers and the securities being sold, emphasizing the firms' obligations to develop effective supervisory procedures. ${ }^{40}$

The Ig64 amendments significantly expanded the disciplinary powers of the SEC, giving it power to proceed against individual registered representatives as well as against broker-dealer firms, to impose a wider range of sanctions including censure and suspension, and to prohibit association of named violators with any broker-dealers. ${ }^{41}$ In addition to seeking revocation or suspension of registration of broker-dealer firms, the Commission has enhanced the effect of such proceedings. by substantial application of its new statutory power to proceed against individuals. In the fiscal years $x 966$ through I 969 the Commission instituted such proceedings against a total of 489 individuals. ${ }^{42}$

Most broker-dealer firms that are members of a registered exchange or of the National Association of Securities Dealers (NASD) have established supervisory procedures designed to minimize the risk of violations by their representatives. The procedures tend to focus upon a wide range of financial standards and rules designed to promote "just and equitable principles of trade;"43 but if carefully followed, they would generally bring questionable transactions in "restricted" securities to the attention of supervising officers. It seems more doubtful whether ordinary supervisory procedures effectively control distributions of securities not stamped with an investment restriction, but there is a growing tendency for firms to establish compliance procedures under a supervising officer designed to focus specifically on compliance with federal securities acts.

Although the formal training of representatives in matters of federal securities law is limited, ${ }^{44}$ the lore of the securities business supplements the formal super-

${ }^{38}$ See, e.g., Gilligan, Will \& Co. v. SEC, 267 F.2d ${ }_{4}^{61}$ (2d Cir. 1959), cert. detried, 36I U.S. 896 . (1959); and list of revocation proceedings, e.g., 26 SEC ANN. REP. 92-I06 (1960).

${ }^{80}$ Release 4445 , Compilation at 45.

${ }^{40}$ Release 5168.

${ }^{12}$ Securities Act of 1934 , I5 U.S.C. $\$ \$ 770(b)(5)(D)$, 770(b)(7) (1971). See generally Grecne, Regulation of Entry Into The Securities Business, in H. WANDER, supra note 36 at 487; Sterling, National Association of Securities Dealers and the Securities Act Amendments of 1964, id. at 495.

${ }^{12} 32$ SEC ANN. Rep. 58 (1966); 33 SEC ANN. Rep. 77 (1967); 34 SEC ANN. Rep. 90 (1968); 35 SEC ANN. REP. 96 (1969).

Is See National Association of Securities Dealers Rules of Fair Practice \$27 (1970), adopted pursuant to 1934 Act, $\$ \$ 15 A(b)(8)$ \& (9), I5 U.S.C. $\$ \$ 80-3$ (b)(8) \& (9) (1970), 1934 Act $\$ 15(b)(10)$, 15 U.S.C. $\$ 780$ (b) (10) (197I), and Securities Exchange Act Reg. I5b10.4, 17 C.F.R. $\$ 240.15$ bro-4 (Supp. 1972); SEC Securities Act Release No. 5168 (July 7, x971).

"See, e.g., National Association of Securities Dealers, NASD Tranning Gutde 96-ir3 (1969). See recommendations for more extensive development of compliance checklists, requirements for internal 
visory structure. Both SEC enforcement personnel and NASD representatives indicate that the availability of the no-action process to clear "investment stock" is well understood by most representatives. And it seems likely that the lore of no-action letters is substantially contributed to by typical SEC investigative practices. Though a no-action letter does not assure immunity, investigations are more likely to focus upon those transactions in which a no-action letter does not appear in the file. ${ }^{45}$ Where an investigator from a regional office is analyzing a large, questionable distribution, he is likely to inquire why a no-action letter was not obtained to support the transaction. ${ }^{46}$

All of these factors undoubtedly resulted in closer control of unregistered distributions in most broker-dealer firms; and, at least until Rule I44 is fully understood, supervisory or compliance officers are much more likely to insist upon either a no-action letter or the opinion of reliable counsel demonstrating the availability of an exemption from registration. However, broker-dealers to whom a proposed sale of "investment stock" is presented are not encouraged to have confidence in the opinion of private counsel. Thus, the Commission's comments in a 1962 release emphasized the unreliability of attorneys' opinions as the basis for a claimed exemption authorizing trading in unregistered securities. Reviewing a case in which reliance upon the advice of counsel had been held sufficient to insulate certain dealers from criminal liability for the sale of unregistered stock, the Commission stated that "the conduct of these dealers did not meet acceptable standards .... It was up to these dealers to make an appropriate investigation as to who their seller was and not simply to rely upon the opinion of the seller's attorney ...."The release emphasized that it is insufficient for dealers simply to obtain factual representations from the sellers and submit those representations to an attorney who supplies an opinion that an exemption is available:

Obviously, an attorney's opinion based upon hypothetical facts is worthless if the facts are not as specified, or if unspecified but vital facts are not considered. Because of this, it is the practice of responsible counsel not to furnish an opinion concerning the availability of an exemption ... unless such counsel have themselves carefully examined all of the relevant circumstances and satisfied themselves, to the extent possible, that the contemplated transaction is, in fact, not a part of an unlawful distribution. Indeed, if an attorney furnishes an opinion based solely upon hypothetical facts which he has made no effort to verify, and if he knows that his opinion will be relied upon as the basis for a substantial distribution of unregistered securities, a serious question arises as to the propriety of his professional conduct. ${ }^{47}$

accounting and oversight of self-regulatory systems proposed in SEC, REPORT OF THE ADVISORY COMMTTTEE on Enforcement Policies and Practices, at I4-I6, 57-6I (I972).

${ }^{45}$ Interview with Mr. Ezra Weiss, then Associate Chief Counsel, Division of Trading and Markets, Securities and Exchange Commission.

${ }^{40} I d$.

"7 Release 4445, Compriation at 45-46, discussing United States v. Crosby, 294 F.2d 928 (2d Cir. 196x). See also SEC Securities Act Release No. 5 r68 (July 7, I97r) CCH FED. SEC. L. REP. I 22,760, indicating that any determination that an exemption exists should be made only after the broker-dealer 
Responsible counsel may legitimately feel some trepidation in rendering opinions based on conclusions of "ultimate fact" about investment intent and involving extensive potential liability. Until recently, relatively few lawyers had studied or had experience with federal securities regulation. While a general understanding of the regulatory theory could be obtained from traditional sources, little material was available reflecting the concrete application of doctrine to the determination of investment intent. Thus, until the recent adoption of a policy making no-action requests and responses publicly available, ${ }^{48}$ those materials were accessible only through private arrangements among SEC practitioners for the exchange and compilation of no-action letters as they were received. But those compilations were not generally accessible to the practitioners most in need of guidan'ce. Furthermore, that condition prevailed in a legal context in which the Disclosure Study, after analyzing the substantive inconsistencies, concluded,

In the area of statutory interpretation which is primarily involved, uncertainty and divergence of practice presently prevail to an unacceptable degree. Greater certainty and predictability are essential.

....

Apart from the mere bulk of requests currently faced by the staff, there is a constant problem in providing reasonably consistent advice. Since the tests with which the staff must work are subjective, its. reactions in given situations depend, to a degree at least, on a "feel" of the transaction conveyed by the request for "no action." Troublesome inconsistency is often the result. Yet that inconsistency, which exists within a relatively compact staff operating under a single director, pales in comparison with the inconsistency in advice given by private counsel as to when and under what circumstances securities sold in private offerings may be resold. ${ }^{49}$

In summary, private offerings have become increasingly popular as a means by which a company may acquire additional capital or compensate employees without undertaking the expense of registration. However, because of the potential liabilities to subsequent purchasers that may result from the sale of the unregistered stock by

has reviewed the facts relating to acquisition of the shares and an opinion has been obtained from "competent outside counsel having no proprietary interest in the offering . . . C Cf. complaint in SEC v. National Student Marketing Corp., [1971-1972 Transfer Binder] CCH FED. SEC. L. REP. 1] 93,360, directly charging two law firms with complicity in anti-fraud violations, including failure to advise the Commission of violations.

${ }^{18}$ SEC Securites Act Release No. 5098 (Oct. 29, 1970) CCH FED. L. REp. I77,921. [Hercinafter cited as Release 5098.] The new policy originated with suggestions by Professor Kenncth Culp Davis which prompted the SEC to request comments "on whether staff interpretative and no-action letters should be made available to the public." SEC Securities Act Release No. 4924 (Sept. 20, 1968) CCH FED. SEC. L. REP. 177,606 . The proposal was also encouraged by Recommendation No. I9 of the Administrative Conference of the United States, adopted by the Conference at its Fourth Plenary Session, June 2-3, 1970. The text of Recommendation I9 closely follows the conclusions and recommendations of the Report from which this article is drawn. See note 3, stpra.

Release 5098 contemplates publication of summaries of the more significant no-action letters in the Commission's News Digest; and a large number of letters have now been published in the current materials supplied with the $\mathrm{CCH}$ and BNA securities law loose-leaf services. See list of "No-action and Interpretative Letters" in 4 CCH FED. SEC. L. REP. \63,20I.

10 Disciosure Study at I52, 176-77. 
the immediate purchaser, the practice of stamping an investment restriction on the face of the stock certificate has increasingly been followed. That investment restriction may appear to the immediate purchaser to be a legalistic formality until he attempts to arrange for the sale of his stock through a broker-dealer. Because of the increasing frequency of Commission disciplinary and enforcement proceedings against broker-dealers, they are sensitized to the danger of selling unregistered "investment stock." When the prospective sale is brought to the attention of a supervising manager of the securities firm, he will ordinarily refuse to allow any sale to be executed until he receives a satisfactory opinion of counsel that a valid statutory exemption is available. Because of the understanding that many counsel will provide any opinion necessary to facilitate clients' sales, and because of Commission warnings that the opinion of private counsel will not necessarily insulate against disciplinary proceedings, many broker-dealers will insist upon a no-action letter unless the stockholder presents an opinion by counsel regarded as reliable. Further, it is a matter of general lore among broker-dealers and registered representatives that the safe thing to do, in any doubtful case, is to insist upon a no-action letter. And the investigation and enforcement practices of the Commission staff substantially contribute to that lore, for experience suggests to dealers that, in routine investigations, much less question is raised about transactions for which a no-action letter appears in the file.

Finally, where counsel is asked to render an opinion on the kind of "ultimate fact" questions involved in determining the availability of an exemption, he may well conclude that the uncertainty of the interpretive rules, or the unavailability of a sufficient number of concrete applications, renders it advisable to take advantage of the no-action procedure rather than risk an independent opinion.

These sources of demand for no-action letters suggest some doubt about whether the demand will diminish. Private offerings continue to produce a significant share of the total estimated gross proceeds from new securities offered. ${ }^{50}$ Undoubtedly, the rules initiated by the Disclosure Study and culminating with the adoption of Rule $144^{51}$ will reduce the uncertainty that prompts many no-action requests. But because the proposed rules are in some respects more rigidly restrictive, and somewhat uncertain with respect to unregistered sales of stock in nonreporting companies, ${ }^{52}$ it seems possible that many transactions that are now executed without

\footnotetext{
${ }^{50}$ See SEC estimates of proceeds from private corporate offerings, e.g., $\$ 2,023,789,000$ in private offerings compared to $\$ 13,288,056,000$ in registered public offerings in period Jan.-Ap. 1971. Securities Offerings, Estimated Gross Proceeds from New Securities Offered for Cash in the United States, SEC Statistical Bull., June 1972, Vol. 31, No. 6, at I6.

It is possible that the substantial narrowing of the private offering exemption by SEC v. Continental Tobacco Co., 463 F.2d I37 (5th Cir. I972), will ultimately reduce the volume of private offerings and of related no-action requests. In the shorter run, however, it seems as likely that narrowing of the exemption may result in an increase in demand for no-action or interpretive letters as counsel seek to clarify the remaining scope of the exemption.

${ }^{21}$ See note 6 , supra, and accompanying text.

"25 Section (c) (2) of Rule $\mathrm{I}_{44}$, requiring certain information to be "publicly available" does not indicate what manner or extent of publicity will satisfy the rule.
} 
notice will be more clearly identified as doubtful transactions. This, in turn, may produce additional requests for no-action letters, particularly for proposed "private transactions," which are not redefined by Rule I44. Obviously, this depends upon what proportion of the existing volume of private transactions are traceable to nonreporting companies.

Other factors may also produce additional demand for no-action letters. A more successful training program for registered representatives may be developed by the NASD, making representatives more aware of doubtful transactions, particularly as a result of the adoption of Rule $\mathrm{I} 44$. The expansion of relevant courses in the law schools and the continuing expansion of practice in that field by inexperienced lawyers both may add to the flow of requests for no-action letters. Continued aggressive enforcement and continuing doubt about the protection furnished by opinions of counsel will continue to induce broker-dealers to seek the security of a no-action letter where questions arise.

For these reasons, it may be desirable for the Commission, as well as other agencies, in structuring their advisory processes, to further consider the impact of enforcement practices, the role of private counsel, and the possibility of avoiding routine "clearances" in order to give more extensive consideration to questions which advance their policy and technical thought, with broader availability and fuller exposition of the grounds for their conclusions. Perhaps most of those goals will be accomplished by the Commission's announcement in connection with its recent adoption of Rule I44 that it will not issue no-action letters for transactions within the coverage of the Rule but will continue to issue interpretive letters. ${ }^{63}$ Those letters, like no-action letters, ${ }^{54}$ will be publicly available. Thus, the public will at least have access to a substantial collection of the staff's explanations and applications of policy. ${ }^{\text {t5 }}$

\section{III}

\section{Organization of the No-Action Process ${ }^{50}$}

The no-action process administered through the Office of the Chief Counsel, Division of Corporation Finance, is a distinct facet of the organization of that Division. The Chief Counsel is assisted in administering the process by two

\footnotetext{
${ }^{53}$ Release 5223.

"Release 5098, announcing the policy of public availability, applies to "interpretative" as well as "no-action" letters.

${ }^{55}$ Staff "no-action" letters, however, seldom contain an exposition of the interpretative basis for the conclusion stated. See text at pages Ir3 \& I20, infra.

${ }^{50}$ Much of the information in the following material was obtained by the author from a series of interviews and examinations of files and records in the SEC's Division of Corporation Finance in 1969-70, and arranged with the cooperation of the Commission and Mr. Philip A. Loomis, Jr., then General Counsel and recently appointed Commissioner, SEC. Particularly helpful and generous with their time were Mr. Courtney Whitney, Jr., then Chief Counsel of the Division of Corporation Finance, and Messrs. John J. Heneghan, William E. Toomey, assistant Chief Counsel, Edmund Shevlin, then Special Counsel, in the Division of Corporation Finance, and George P. Michaely, Jr., former Chief Counsel of the Division.
} 
Assistant Chief Counsel (hereafter, "Assistants"), who devote at least seventy-five per cent of their time to the process. They, in turn, are assisted by approximately forty staff attorneys from the various sections of the Division who, on the average, devote slightly more than fifteen per cent of their time to the process. Two or three special counsel in the office of the Chief Counsel also assist in the process on special assignments from the Chief Counsel or his Assistants. The Division is organized into fifteen branches for the primary purpose of processing 1933 Act registration statements and letters of comment and 1934 Act reports and proxy materials. Each branch of the Division bears responsibility for processing these materials for an assigned group of companies, with new companies being assigned to the branches on a rotating basis. The branch chiefs are responsible to the Director of the Division for branch performance of these duties.

The no-action process administered by the Chief Counsel's office cuts vertically through this organizational structure; the staff attorneys in the various branches are directly responsible to the Chief Counsel's office for their performance. Assignments to prepare responses to requests for no-action letters are made to the staff attorneys by the senior Assistant through the branch chief or the senior attorney in the branch, who attempts to balance the work load.

All requests for advice respecting the need to register stock to be offered for sale, as well as other requests for information, are channeled from the branches to the Chief Counsel's office. (Exceptions are occasional calls received by a branch attorney who has previously dealt with a party or his attorney.) Verbal requests are generally handled as abstract interpretive questions, with only general guidelines stated. Conversations looking to submission of a no-action letter may become more specific in identifying key issues, and verbal disapproval of a proposal may be offered; but, as a rule, no concrete conclusions approving a course of action are expressed orally. Where the advice sought involves a request for approval of a specific course of action, the parties are asked to submit a written statement of all of the pertinent facts and to request a no-action letter.

All written requests for a no-action letter are initially channeled through the senior Assistant, who makes a rough appraisal of the problems they present and assigns them to a branch. (He may occasionally retain a particularly difficult problem or assign it to one of the special counsel in the Chief Counsel's office.) The letters are assigned to the various branches according to the name of the company whose stock is to be offered for sale; the branch which has previously dealt with a company in connection with a prior registration or other matter will be assigned the no-action letters involving that company's stock. Where new companies are involved, those companies and letters relating to them are assigned to the branches on a rotating basis.

After the branch chief or senior branch attorney assigns a staff attorney to the problem, he would ordinarily proceed as follows to handle the matter: 
(I) analyze the apparent problems presented by the request;

(2) write (or occasionally call) to ask for a further statement of facts if essential facts are missing;

(3) conduct a file search to determine:

(a) whether the company has filed a registration statement with the Commission;

(b) whether the company is registered under the Securities and Exchange Act of 1934 and is currently rendering reports to the Commission pursuant to that Act;

(c) whether the files indicate any securities violations by the companies or individuals involved, and if so, whether those violations are current;

(d) the current price at which the stock is trading and the current trading volume, if available; and

(e) whether the essential facts stated in the requesting letter comport with the information about the company on file with the Commission (This search generally will involve a rudimentary examination of the amount of stock issued and outstanding, the relationship of "control" persons, and a quick search of the general correspondence file on each company. If possible inconsistencies with the facts stated in the requesting letter appear, a more thorough search will be conducted);

(4) do necessary research, if any;

(5) prepare a recommended response and submit it to the Assistant, together with the requesting letter, and a form reflecting the information obtained in the file search; and

(6) in a very few cases the branch attorney may be asked to prepare a memo explaining the reason for his conclusion.

The recommended response, as submitted by the branch attorney, is then reviewed by one of the Assistants, who signs the letter (under his title) if he finds it satisfactory. In a large proportion of the cases, however, the Assistant revises the - recommended letter, often (30-40 per cent of cases) reversing the conclusion recommended by the staff attorney. In other (10-20 per cent) cases, he may revise the form or content of the letter. Where the conclusion is reversed, the practices of the two Assistants diverge: unless the reason for the staff attorney's different conclusion is readily apparent (and reasonable), one Assistant discusses the matter with the originating staff attorney and explains the reason for his different conclusion; the other seldom discusses the change. In every case, however, the staff attorney is notified of the final result by receiving a copy of the responding letter in the 'form in which it was sent:

Where a-no-action request presents a particularly difficult or unusual problem, 
the Assistants may discuss the matter with the Chief Counsel or Director of the Division before rendering their final determination. In some of those cases, or where the matter has been extensively discussed between the Chief Counsel and counsel for the stockholder, the Chief Counsel may sign, or prepare and sign, the letter. He also prepares some letters from time to time on a regular basis, though the total number handled by the Chief Counsel is small. One former Chief Counsel estimated that a relatively small proportion of his time (not more than I0-I5 per cent) is devoted to the no-action process. His predecessor, however, estimated that he spent closer to half of his time on no-action matters. The disparity is probably explained by a recent Commission change of procedures designed to minimize the number of no-action matters brought up for Commission consideration. ${ }^{57}$

The no-action process appears to be administered on a substantially current basis. Relatively few cases involving significant delay appeared, and, where delay occurred, it often resulted from requests that the applicant supply more factual data. A random sampling of the letters issued in 1969 indicated that approximately half of the affirmative responses and 70 per cent of the negative responses had been pending for approximately one month or less, 30 per cent of the affirmative responses and 20 per cent of the negative responses had been pending for approximately two months, and an additional 20 per cent of the affirmative responses and ro per cent of the negative responses had been pending longer than two months. Most of those pending more than two months had involved some additional correspondence intervening between the request and the concluding response.

The relative currency of the process is undoubtedly due to an effective check-off process maintained by the senior Assistant. He keeps track of every assignment of a no-action matter to a staff attorney and prods those who are slow in responding. While this presents some problem because the staff attorneys are primarily responsible to their branch chiefs, the system seems to be operating satisfactorily.

\section{IV}

\section{InItTATton of the Process}

\section{A. The Parties}

As indicated, the applicant for a no-action letter is generally a stockholder who seeks to sell his stock without registration. In some instances, the applicant may be a promoter of a new company, seeking exemption for an initial issue, or a promoter of a merger, seeking assurance that the merged company's stockholders may receive or dispose of the surviving company's unregistered "stock. And, occasionally, a pledgee seeks to realize upon pledged stock by obtaining a no-action letter authorizing sale. Although many other parties, such as broker-dealers, may be interested in particular transactions, it is not the practice for interested parties to apply or intervene;

\footnotetext{
${ }^{67}$ See text at page II5, infra.
} 
and, in view of the substantive questions usually at issue, it seems doubtful that intervention would serve any purpose.

There are, however, some circumstances where the interests of third parties appear to affect staff or Commission judgments. For example, in one instance the Commission appeared to take into account the fear of administration officials that denial of an exemption and the resultant closing of the applicant's plant (for lack of funds) would produce unemployment in an already depressed area. ${ }^{68}$

While such informal intervention on behalf of applicants by administration officials appears to be rare, intervention by members of Congress is much more common. For example, a spot check showed responses to nine inquiries from congressmen during the period of April I-I8, I969, a period in which 2I8 no-action letters were sent. Almost invariably, such an inquiry results in preparation of a memorandum for submission to the congressman, explaining the circumstances, the status of the no-action request, and the basic statutory theory supporting the staff or Commission disposition of the matter. However, intervention by members of Congress apparently has little effect on the disposition of no-action matters. ${ }^{60}$

\section{B. The Form of Advice Sought}

Most questions relating to registration obligations are directed to the Chief Counsel's office in the Division, and that office responds to $75^{-100}$ telephone calls per week involving requests for interpretive advice. The Chief Counsel and his Assistants give considerable oral advice about interpretive problems presented by particular transactions, but most such advice is designed to identify specific problems which are left for ultimate resolution by counsel. The staff generally will not express specific conclusions about the legal consequences of specific courses of action without a written request detailing all pertinent facts. Where the parties seek ultimate conclusions about the application of interpretive concepts to specific facts, particularly where inquiries relate to the "underwriter" problems that dominate the no-action process, the parties will be urged to submit a written request for a no-action letter. In such cases, oral advice will be directed to explaining the kinds of facts that may be helpful in submitting a no-action request.

At an earlier date, many no-action matters were handled by a conference at which the applicant's attorney appeared, bearing the form of no-action letter for which he sought staff approval. The issues presented were debated and often resolved in personal conferences, with the letter issuing immediately. Such conferences now play a considerably less significant role in the no-action process, and the responding letter is no longer negotiated and executed in the course of the conference. Personal conferences do, however, continue to provide an effective forum for advocacy on behalf of a particular application, with some apparent effect upon the outcome in some cases.

\footnotetext{
${ }^{88}$ See Commission action on no-action request, reversing the staff position, app. B, ๆ B.

${ }^{60}$ See text at page 127 , infra.
} 
There is no prescribed procedure for recording telephone or personal conferences. Some attorneys maintain a log of calls while most apparently do not. Where the information provided is material, notes are inserted in the correspondence file and generally referred to as the basis for factual recitations in a later responding letter.

As might be expected, in view of the clearance function they perform, no-action letters make up the bulk of letters processed in the Office of Chief Counsel of the Division. A sampling of 322 letters issued in the period April I-I8, I969, revealed that 218 were no-action letters in the sense that they merely recited facts and stated conclusions respecting the obligation to register stock rather than overtly explaining the basis for the conclusions. Only seven letters in that period provided any detailed discussion of interpretative problems-but they took no position on enforcement prospects. The remaining ninety-seven letters were for general administrative or informational purposes.

\section{$\mathrm{V}$ \\ Processing No-Action Letters}

\section{A. Defining the Questions to be Answered}

The no-action process does not provide any routine method for assuring that applicants understand the factual and legal questions that may determine the result of their request. Generally the written requests for no-action letters do not pose the specific questions to be answered but merely recite facts relating to the amount of stock held, the source, date and price of the acquisition, and the extent of other holdings in the same stock, with source, date, and price of those acquisitions. A survey of the staff preparing responses indicates that the no-action requests expressly state the determinative legal or interpretive question in about 35 per cent of the applications. When the applicant identifies the question, however, he is correct (in the staff attorney's view) in about 80 per cent of the cases. ${ }^{60}$

Where a request for a no-action letter provides insufficient information, the staff attorney ordinarily will respond with a written request for additional facts. That inquiry, however, seldom expressly identifies the questions considered to be at issue. (And in a large number of routine requests, of course, the questions merely seek to establish the source of acquisition, the length of the holding period, and the reason for the present desire to sell.)

More often, a telephone inquiry by the staff attorney or a status inquiry by the

\footnotetext{
${ }^{\circ 0} \mathrm{~A}$ questionnaire submitted to forty-three staff attorneys in the Division of Corporation Finance. Probably because of the length and complexity of the questionnaire, only ten replies were received. Five of the replies were from attorneys who had been handling no-action matters for one year or less, and three from attorneys with experience of six months or less. On the other hand, four responses came from attorneys with experience ranging from $I \frac{1}{2}$ to $3 \frac{1 / 2}{2}$ years. In view of the relative instability of theforce of attorneys in the Division as a whole, this is probably a satisfactory cross-section.

The entire questionnaire, with a profile of the responses to each question, is set forth as app. I to Report, supra note 3 . The $80 \%$ figure cited in the text is taken from the responses to question I3 $_{3}$ of that questionnaire. Subsequent data drawn from the questionnaire will be cited herein as: Questionnaire, supra note 60, question —.
} 
applicant may result in a telephone or personal conversation which identifies the key issues. But staff attorneys estimate that in more than half of the cases there is no communication with the applicant that specifically identifies the determinative question. ${ }^{61}$ In most of those cases, however, the nature of the inquiry is undoubtedly so routine that the staff assumes that the determinative issue is understood. And in many of those cases the staff's reasoning is apparent from its comment that it is unable to grant the request "in view of the short holding period."

The more sophisticated SEC practitioners, on occasion, will provide a full statement of facts, followed by a statement of their interpretive reasoning in support of the opinion which they propose to give their clients, concluding with a request that the Division indicate its concurrence. However, staff conclusions apparently do not turn on the form of application. Some staff attorneys suggest that counsel may often want to avoid committing themselves to a single rationale, or may hesitate to focus attention upon a particular problem.

Although the power to deny a no-action letter would seem to give the staff substantial power to compel modification of proposed transactions, it does not appear that the power is used extensively. Where discussion initiated by the applicant or his counsel focuses on available alternatives, staff attorneys may occasionally suggest specific modifications of a transaction. And in a few instances the Commission has suggested that a specific limiting commitment would enable it to authorize a no-action position. Ordinarily, however, where revisions are made to assure favorable treatment, the suggestion is offered by counsel for the applicant.

While discretionary factors may often play a substantial role in the staff and Commission decision, few applications address any argument to such matters. Sophisticated SEC practitioners will occasionally point out that the volume of transactions in the stock in question is sufficient to assure that the market will not be affected by the sale and that no special commission inducements will be necessary. And the relative insignificance of the holdings involved, compared to the total stock outstanding, will often be pointed out. But factors such as the difficulty of obtaining the issuer's agreement to register, or the pendency of enforcement proceedings and the applicant's relation to those proceedings, are seldom mentioned in the applicant's letter.

\section{B. Establishing the Facts}

No-action advice is usually given hypothetically in the sense that the staff does not purport to determine questions of evidentiary fact. However, the staff insists that it will not give no-action advice without a full statement from the applicant of the facts material to the transaction in question. ${ }^{62}$ The letters essentially treat those statements as affidavits, scrupulously referring to or incorporating the factual assertions

\footnotetext{
${ }^{11}$ Questionnaire, supra note 60, questions 15 and 16.

02 In a recent release outlining the procedure for "no-action" or interpretative letters, the Commission .emphasized that "letters relating to unnamed companies or persons, or to hypothetical situations, will not be answered." SEC Securities Act Release No. 5 r27 (Jan. 25, r97r) CCH FED. SEc. L. REp. १66,48r.ro.
} 
in the applicant's letter. But, with minor exceptions, no proof is required of the facts asserted by the applicant. This would seem to conflict with the Commission's own assertion that a "serious question" concerning the propriety of an attorney's conduct would arise if he "furnishes an opinion based solely upon hypothetical facts which he has made no effort to verify," knowing that his opinion will be relied upon to support distribution of unregistered securities. ${ }^{63}$ It does appear that some of the asserted facts are verified against information available in the Commission's files. Ordinarily, however, those files would not provide means of verifying the transaction by which the shares were acquired unless they were acquired directly from the issuer. And even that information may be unavailable with respect to nonreporting companies.

It is estimated by the senior Assistant that the facts initially provided by the applicant are inadequate in about $3^{\circ}$ per cent of the cases. In all but about to per cent of the cases the missing facts can be supplied from Commission files in the course of a routine check of the issuer's file. ${ }^{64}$ But in only a negligible number of cases are the facts asserted by the applicant materially inconsistent with facts found in the routine check of the issuer's file.

Though the staff seldom requires substantiation of factual assertions, it may make routine inquiries where the applicant has not supplied sufficient information about the source or period of his holdings. And submission of an unaudited statement of the applicant's financial position, both currently and at the time that he acquired the stock in question, is frequently required. But in exceptional cases, the staff may require some further substantiation of the applicant's assertions. For example, an applicant who claims that a medical problem created a serious change of financial position may be asked to submit a doctor's certification. In other instances, applicants have been required to furnish a cancelled check to demonstrate the date of purchase of the stock in question or to furnish a copy of an employment contract on which a claimed "change of circumstances" is based.

\section{Research}

The available research tools, in addition to those publicly available, include the following internal sources:

(a) a monthly summary of interpretations which recites the basic facts and reasoning of the more significant no-action matters passed on each month by the staff. The summary does not include the text of the related letter, but contains considerably more explanation of the grounds for the result than do the no-action letters.

(b) a large card file containing the same summaries of interpretations, in which

\footnotetext{
${ }^{03}$ Release 4445; see also SEC Securities Act Release No. 5 I68 (July 7, 197r) CCH Fed. SEC. L. REP. I 22,760 .

of Questionnaire responses suggest that it may be necessary to obtain additional facts from the applicant in $20-25 \%$ of the cases. Questionnaire, supra note 60 , question ro.
} 
the cumulative production of the monthly summaries is filed. The cards are indexed by subject heading and by statutory section, and are cross-referenced to the significant questions involved in each case summarized.

(c) a file of legal memos on' selected problem areas is maintained in a file alongside the card file. Relatively few memos have been added to that file in recent times.

(d) "The Bible," an analytical treatise prepared for use and maintenance in the office of the Chief Counsel which analyzes the construction of each section of the I933 Act.

(e) a file of Commission minutes which includes the related staff memos submitted to the Commission explaining the staff conclusions on no-action matters brought to the Commission for consideration.

(f) a chronological file of all letters and memoranda rendered by the Office of Chief Counsel, Division of Corporation Finance, which includes all no-action letters issued..$^{65}$

(g) a listing of all companies for which Commission files are maintained, with a classification code keyed to identify companies in which similar disclosure problems were encountered.

The summaries of interpretations are never prepared by the originating staff attorneys. Rather, they are (or were) prepared by a law student clerk under the supervision of the senior Assistant. The usual practice is for the compiler, monthly, to select for summary a group of the more significant no-action letters sent by the Office. Occasionally letters will have been marked for summary during preparationparticularly those signed by the Director of the Division. From the selected group of letters, the Assistant Chief Counsel selects those to be summarized. The compiler summarizes the facts and reasoning underlying the letter and submits the summaries to the Assistant for review and approval. Those summaries are then utilized both in the card file of interpretations and in the monthly summary sheets distributed to the staff attorneys.

While the criterion for selection of no-action letters for summary is somewhat unclear, the general understanding of the compiler is that he is to select the cases that have "precedential value." However, he is instructed not to prepare cards on "questions of fact" such as "control" or "change of circumstances," because each case is viewed as limited to its own facts. On the other hand, he usually selects most cases which are the subject of Commission action as reflected in Commission minutes.

Responses to inquiries with the staff suggest that none of the available internal research sources are very heavily utilized. Most favored by some staff attorneys is reference to a personally-complied file of previous no-action letters, which apparently is consulted in somewhat more than half of the cases by those who use

\footnotetext{
${ }^{O S}$ The no-action letters and interpretive letters have been made available for public inspection and copying as a result of a recent change of policy. See Release 5098.
} 
such a file regularly ( $3^{\circ}$ per cent of respondents). Next most frequently relied upon, in 20-30 per cent of the cases, by less than half of the respondings attorneys, are personal conferences with other staff attorneys. And the card file of interpretive summaries, running a poor third, is apparently used quite infrequently. ${ }^{66}$

Virtually no research use appears to be made of the monthly summaries of interpretations that are distributed to all staff attorneys. Apparently this results from the absence of any indexing system. All of the same information is available in indexed form in the card file of summaries, but use of the card file requires the staff attorney to go to the library in the offices of the Chief Counsel.

In considering the relatively infrequent use made by the staff attorneys of the available internal research sources, it should be remembered that the routine nature of most of the no-action matters invites little research. Furthermore, the ad hoc and subjective quality of the typical determinations of "ultimate fact" tend to encourage the view that conclusions are to be drawn from the facts and not from research. Thus, though the Assistant Chief Council attempts to promote a view of no-action matters as legal and interpretive questions, rather than exercises of discretion, it seems doubtful that that view is generally accepted in the staff. Questionnaire responses indicate that the less-experienced staff attorneys find their own "reservoir of experience" sufficient in 70 per cent of the cases, and the more-experienced staff attorneys in almost 90 per cent of the cases. ${ }^{67}$

\section{Review}

Internal review of staff responses to no-action requests is the primary responsibility of the two Assistant Chief Counsel of the Division, and their efforts in this regard appear to be thorough. Staff attorneys submit a proposed form of response to one of the two Assistants who, after review and any necessary revision, sends the letter over his own name and title. Review by the Assistants appears to be demanding and results in reversal of the disposition recommended by the staff attorney in $3^{0-40}$ per cent of the cases. ${ }^{68}$ To a large extent, the review process is viewed as a training opportunity, providing the Assistant Chief Counsel an opportunity to discuss the matter with the staff attorneys wherever the initial draft suggests misunderstanding or inadequate research.

Unless a specific request is made, applicants are not informed of the staff's conclusion prior to their receipt of the responding staff letter. Therefore, most opportunity for argument arises in the course of the staff attorney's preparation of a recommended response. After receiving a response and upon inquiry (but not in the

\footnotetext{
${ }^{\circ 0}$ Questionnaire, supra note 60, question 27.

${ }^{87}$ Questionnaire, supra note 60, question 29.

${ }^{88}$ Staff attorneys apparently consider the rate of reversal to be much lower: slightly less than $5 \%$. Questionnaire, supra note 60, question 25. That disparity may be explained, in part, by the fact that one of the Assistants seldom discusses revisions with the staff attorneys. The other Assistant frequently discusses the matter with the originating staff attorney, suggesting areas for further inquiry, without expressly rejecting the proposed letter. In all instances, however, the originating staff attorney receives a copy of the letter in final form.
} 
written response), applicants are advised that they may submit additional facts or argument for staff consideration. But in a large proportion of the cases (70-90 per cent), nothing further is heard from the applicant after the response is sent.

No information is volunteered to applicants about the possibility of appealing staff advice to the Commission, ${ }^{69}$ and disclaimers by the staff of authority to speak for the Commission may lead many applicants to suppose that appeal is unavailable. However, Commission minutes indicate that it generally undertakes to dispose authoritatively of those no-action matters brought to it by the staff for consideration. ${ }^{70}$ Upon inquiry about the possibility of appeal, an applicant will be advised that he may request the staff to bring the matter before the Commission; and all such requests are, in fact, brought to the Commission. However, the applicant is not invited to appear before the Commission or to make a written submission, and he is discouraged from requesting an appearance or making a submission in at least two ways. First, upon asking about the availability of a procedure for taking the no-action matter to the Commission, the standard response is along these lines:

You may request to have your matter brought to the Commission for consideration. This is the procedure: We [the staff] prepare a statement of the facts and a memo in which we present your position and arguments and the staff's position and arguments, together with our recommendations to the Commission.

Second, no mention is generally made of an opportunity to appear before the Commission. And where an applicant inquires about the possibility of an appearance, the standard response is: "You have a right to request to be heard, but such requests are seldom granted." Generally the staff memo submitted to the Commission in such matters recommends against hearing the applicant or his attorney, on the ground that the staff believes he has nothing to add to the arguments submitted on his behalf by the staff.

Much of the staff resistance to appeals arises from a sense of obligation to preserve the Commission's time for more important matters. Until recently the staff had been operating under instructions to bring to the Commission all no-action matters involving a proposed offering valued at $\$ \mathrm{I}$ million or more. As a result, though the Commission encouraged the staff not to adhere religiously to that rule, a substantial number of no-action matters were brought to the Commission at the instance of the staff in addition to those appeals arising. from an applicant's persistence. However, most cases brought by the staff for Commission consideration were selected in order to obtain a clarification of policy.

The Commission has recently taken two steps in addition to Rule 144 designed

\footnotetext{
${ }^{60}$ I7 G.F.R. $\$ 202.1$ (d) (Supp. I97I) advises that:

In certain instances an informal statement of the views of the Commission may be obtained. The staff, upon request or on its own motion, will generally present questions to the Commission which involve matters of substantial importance and where the issues are novel or highly complex, although the granting of a request for an informal statement by the Commission is entirely within its discretion.

${ }^{70}$ See text beginning at page 116 , supra.
} 
to reduce the burden of no-action matters reaching it for review: The "automatic appeal" rule for matters exceeding \$I million has been withdrawn, and the Commission's "duty officer," a single Commissioner on a rotating assignment, has been delegated the power "to determine whether the Commission should or should not grant a request for Commission review of a no-action request which had been denied by the Division."71

The urge to protect the Commission from an excessive burden of no-action matters may also be partly responsible for the "cave-in" phenomenon-the staff's reversing an earlier denial rather than complying with a request for Commission review. It is difficult to trace concrete examples of that phenomenon, but it is acknowledged by the senior Assistant that such "cave-ins" occur from time to time where the staff regards an issue as a "close question." On the other hand, it has been asserted that the reason for the "cave-in" may be the staff's reluctance to give the Commission an occasion for reversing a favored interpretive position. In any event, the "cave-in" practice is recognized among knowledgeable SEC practitioners and presents difficult ethical problems. A request for a Commission hearing is thought to consume the staff's "good will"-with the result that counsel must choose which clients are entitled to deplete his "good will" with the staff.

In most instances, the form of Commission action in reviewing no-action matters appears to involve an authoritative Commission disposition, effectively constituting an "order." A typical minute entry relating to a no-action matter may read,

Upon the recommendation of the Division of Corporation Finance, . . . the Commission denied the request of Mr. A for a "no-action" letter with respect to his proposed sale of - shares of $\mathrm{X}$ Corporation common stock and also denied his request to be heard by the Commission in the matter.

Or in another form,

For the reasons stated in a memorandum dated

Division of Corporation Finance recommended that the "no-action" request be granted. That recommendation was approved.

While the reasons for the Commission dispositions are seldom reflected in the minute entries, there is no doubt that the Commission takes specific action on the particular case brought before it. There is no basis for supposing that it merely gives general approval or policy direction to an informal staff process which it authorizes but does not adopt.

An examination of Commission minutes for the period May ro, Ig67, through May I4, I968, revealed that forty-five no-action matters were brought before the Commission for consideration. It is not apparent how many were brought at the instance of the applicant, but in nine instances the papers accompanying the submission to the Commission indicated that a request for appearance had been made. Five cases reflect an appearance by counsel, while four cases expressly reflect the

\footnotetext{
${ }^{71}$ Securities \& Exchange Commission Minute, May I9, I970.
} 
Commission's refusal to hear counsel. The dispositions of these no-action matters by the Commission are reflected in the following chart drawn from a review of Commission minutes and related staff memoranda. ${ }^{72}$

Period: ro May rg67-14 May rg68

No-action matters before the Commission

Commission reversals of staff recommendations 4

Reversals of recommended denials of sale I

Reversals of recommended approvals of sale 3

Commission acceptance of recommended denials of sale ig

Commission acceptance of recommended approval of sale 20

\section{E. Form of the No-Action Statement}

Typically, a no-action letter makes reference to the requesting letter, recites all of the material facts supplied by the applicant (making reference to the source) or incorporates the applicant's letter by reference, and states a conclusion. The conclusions of no-action letters typically follow the conclusory and stylized patterns set forth in Appendix A, providing little or no explanation of the result.

In an effort to reduce the burdens of the no-action process, the Division at present frequently follows the practice of merely incorporating the applicant's letter without repeating the facts. Obviously this practice would make no-action letters themselves much less useful as precedent, particularly where additional facts may have been acquired from direct conversations or from internal sources. Some staff members also suggest that failure to repeat the facts renders no-action letters much less reliable as a protection for brokers who are asked to execute transactions in the unregistered stock, for it will be more difficult to satisfy their duty to investigate their seller.

\section{VI}

\section{Relation of No-Action Letters to Compliance Programs}

Former SEC Chairman Cohen has commented that the no-action process is an area "where an ounce of prevention is worth ... a pound of enforcement."73 That view of the compliance benefits of the no-action process is widely held among the senior administrators on the SEC staff, and is probably well-founded. Yet that conclusion seems to be based primarily upon the administrators' experienced "feel" for their subject as no available studies indicate how effectively the compliance benefits of the no-action process have reached into the securities business. Surely the results of the no-action process do not overwhelmingly favor the applicant-a fact which

\footnotetext{
${ }^{72}$ In the period from June 4-December 30, I968, only II no-action matters were brought before the Commission, and in each instance it approved the staff's recommendation that sale be permitted without restriction.

${ }^{78}$ Panel, Public Information Act And Interpretative And Advisory Ruling, 20 Av. L. REv. I, 24 (1967).
} 
could induce many stockholders and brokers to take their chances rather than draw regulatory attention to a proposed transaction.

Earlier discussion suggests that the Division's liberal advisory practices, together with very real disciplinary threats and, until recently, the absence of dependable or helpful case law, have produced a heavy demand for no-action letters and may continue to produce that demand. But no studies indicate how extensively the educational effects of the advisory processes have pervaded the industry. Discussions with NASD personnel suggest that understanding among dealers may be limited to the view that stock with a restrictive legend may not be sold without a no-action clearance. There may be general understanding of the obligation to investigate "control" persons, but it is likely that most registered representatives make little or no effort at investigation unless they are independently aware of a seller's controlling status. And there may be little or no understanding of the need to determine whether a holder of unlegended stock may have obtained that stock from a controlling person. In any event, it is clear that nothing in the NASD training program for registered representatives deals adequately with these problems; and there is nothing in the exams for either principals or registered representatives dealing with them. ${ }^{74}$

There are no studies to indicate the extent of actual compliance where the staff refuses to take a no-action position. It may be inferred that most stockholders would comply. And those who understand the securities laws should, of course, be aware that a sale following the staff's refusal could provide the basis for a charge of willful violation. But neither studies nor enforcement programs have focussed upon the effect of a staff refusal, and all conclusions in this area must be based on inference.

Enforcement personnel generally regard no-action letters as an important part of the compliance program. Copies of all no-action letters are sent to the Regional (enforcement) Office nearest the city in which the proposed transaction would occur. But compliance programs are not based upon follow-up of staff refusals of no-action positions, and very few enforcement proceedings arise in that manner. Rather, no-action letters enable enforcement personnel in the Regional Offices to keep up with what is happening with particular companies and in the business generally and with the staff's thinking on particular interpretive and enforcement problems. Occasionally a letter may prompt enforcement personnel to object to a specific staff position, particularly if the same or similar transactions are under investigation in the field. To those ends, the letters are circulated among the senior personnel in the Regional Offices.

Where an investigation or enforcement proceeding is already underway, the noaction process is administered to minimize the probability of any further illegal

\footnotetext{
74 See National Association of Securities Deazers, NASD Training Guide (1969); Interview with Mr. Lloyd Derrickson, then General Counsel, National Association of Securities Dealers and NASD personnel responsible for training programs. But see note 44 , supra.
} 
distributions that might prove damaging to purchasing stockholders. Thus, the processing of no-action letters routinely involves a file check to determine the pendency of any investigations. Typically, where an investigation is pending, the staff will refuse to take a no-action position via a written response that is almost totally uncommunicative. (See Appendix B, paragraph A.)

Thus, it appears that the primary compliance benefits of the advisory process are in educating the industry for, and encouraging, voluntary compliance. It remains to be demonstrated that an unconstrained advisory process, providing routine clearances for sales, is the best means of achieving that end. The Commission apparently concluded that it was not, in deciding to limit the availability of noaction letters after the effective date of Rule $144^{75}$

\section{No-Action Letters As Nonpublic Public Law}

In considering the status of no-action letters as "law," three different products of the no-action process should be segregated: (a) Commission "orders" determining an applicant's entitlement to a no-action letter, together with the related no-action response, staff memoranda to the Commission, and any interpretive summaries reflecting the result; (b) no-action letters which, though not reviewed by the Commission, provide the basis for internally-distributed interpretive summaries; and (c) other no-action letters rendered by the staff which are neither reviewed by the Commission nor summarized for internal distribution.

The Commission-reviewed no-action positions and accompanying statements would seem, from counsel's perspective, to constitute "law," for they involve a final official disposition of a concrete claim not unlike the mass of case law on which lawyers commonly rely for guidance. Surely such determinations are "orders" within the meaning of section 2(d) of the Administrative Procedure Act, for the agency renders "a final disposition ... declaratory in form ... in a matter other than rule making but including licensing. "76 And such orders may well constitute a "license" within the broad language of section $2(e)$ for in reality they constitute a "form of permission." Furthermore, the staff and Commission appear to treat prior Commission-approved no-action dispositions as precedent. Throughout the sup: porting memoranda there are frequent citations to the precedents found in prior no-action dispositions, with many general citations and frequent specific citations. Thus, in the forty-five no-action dispositions by the Commission between ro May I967 and I4 May I968, there were at least fourteen specific citations to prior Commission-approved no-action dispositions. ${ }^{77}$

\footnotetext{
${ }^{75}$ See notc 53 supra, and accompanying text.

${ }^{7}$ Cf. Medical Comm. for Human Rights v. SEC, 432 F.2d 659 (D.C. Cir. r97o), judgment vacated as moot, 40I U.S. 973, 40 L.W. 4117 (1972). But see First Savings \& Loan Ass'n of the Bahamas, Ltd. v. SEC, 358 F.2d $35^{8}$ (5th Cir: I966); Mattson v. Medical Development Corp. v. SEC, 329 F. Supp. 304 (D. Utah I97I).

${ }^{77}$ See summary of staff citations to no-action dispositions compiled in App. G of Reporr, supra note
} 
In considering the Commission dispositions as "law," it is important to recognize that they assume that status because they reflect Commission action and not because they are interpretive or analytical in form. The Commission minutes ordinarily do not reflect the Commission's reasons for its conclusions in particular no-action matters, and the reasons must be inferred from the facts, interpretations, and discretionary considerations set forth in the accompanying staff memoranda. While the Commission actions would seem to involve "interpretations," there is no assurance that that is the case, for often they may also reflect such other concerns as the hardship imposed by compelling rigid compliance with registration requirements, an assessment of the "quality" of the company and the probability of injury to a purchasing stockholder if the proposed sales are made, and similar "discretionary" considerations. $^{78}$

The same considerations affect the interpretive understanding to be gleaned from no-action letters except those very few that are, in form, expressly interpretive. The former Chief Counsel of the Division of Corporation Finance has commented:

I do not believe it is helpful ... to attempt to make a distinction between noaction and interpretive letters .... By far the more numerous are those situations in which it is difficult, if not impossible, to tell whether the staff advice is intended as an interpretation, or merely as a statement that enforcement action will not be taken. ... It is difficult for the reader to make a distinction between the two types of letters because of the rather peculiar phraseology . . . but more importantly because it is impossible for the reader to know what factors were, in the mind of the staff member who wrote the letter, determinative of the position taken. . . . Also, it is not always clear to the staff member whether he intends that the letter constitute an interpretation or merely a statement that enforcement action will not be taken. . . . It was my experience that normally when a request for advice was referred to the Commission ... . [it] considered the question as one of interpretation of the securities laws. This was true even though the person who had requested the advice may have desired nothing more than an assurance that no enforcement action would be instituted. . . . Conversely, in some instances when the staff referred matters to the Commission as interpretive questions, the Commission disposed of them as if they were nothing more than requests for assurance that no enforcement action would be instituted.79

The uncertainty created by the interaction of legal interpretation and discretionary enforcement policy necessitates careful appraisal of the statements of Commission and staff in order to reach a judgment about their interpretations or policies. But uncertainty about the motivations for official decisions is a problem that lawyers must continually puzzle from their days as first-year law students. That uncertainty

3. See the frequent citations to the authority of previous no-action positions in the memorandum supporting the staff position set forth in App. L-I of REPORT, stepra note 3. (This latter action is described in App. $B$, I A, infra.)

${ }^{78}$ See letter of George P. Michaely, Ir., former Chief Counsel, SEC Division of Corporation Finance, App. B. of Report, supra note 3.

${ }^{70}$ Id. 
renders the "no-action" decision no less "law," whether rendered by the Commission or by the staff.

Whether the staff interpretations, as reflected either in the original no-action letters or in those letters taken together with related interpretive summaries, are "law" must depend upon the purpose for which that question is asked. For example, it seems likely that the summaries of interpretation, together with the applicable no-action letters, may well be viewed as "instructions to staff that affect any member of the public" within the meaning of the Public Information Act. ${ }^{80}$

There can be little doubt that the interpretive summaries, whether based upon a Commission disposition or upon an unreviewed staff letter, provide a body of internal precedents which "affect" members of the public who request no-action letters. The senior staff counsel regard it as their function to maintain internal consistency in rendering no-action letters, and to that end the staff attorneys are urged to view the problems presented by no-action requests as legal questions to be resolved by traditional legal, interpretive techniques. The entire process of summarizing and circulating interpretive statements and maintaining a card file of interpretations can only be intended for that purpose. Thus, the senior Assistant states that he particularly expects the newer staff attorneys to "spend a lot of time in the cards," and he discourages them from basing their recommended decisions on "discretionary" factors.

Of course it is essential to recognize that both the senior counsel and the staff attorneys are agreed that a large proportion of the routine no-action letters are not of precedential value. ${ }^{81}$ In large part this is due to the routine nature of the questions usually presented, which also results in the relatively low staff use of the internal research tools. But use of the research tools continues at a rate roughly comparable to that proportion of cases in which the staff attorneys find their experience inadequate for preparation of a no-action response. ${ }^{82}$

Another factor of importance which contributes to the view that many no-action matters are not of precedential importance is the widely held staff position that many no-action matters reflect only conclusions of "ultimate fact" peculiar to the facts of a particular case. Thus, the practice has developed of treating most "change of circumstance" claims as single unique cases without precedential value. Yet certain patterns of decision are surely reflected in those cases. For example, it seems likely that the worsening of a medical condition that existed at the time of purchase of the stock in question will not support a claim of "changed circumstances," though such a claim may be based upon a new medical condition that arises after purchase of the stock. But if the medical condition, though it subsisted at the time of purchase,

\footnotetext{
${ }^{80} 5$ U.S.C.A. $\$ 552(2)(2)(C)(1967)$.

${ }^{81}$ Questionnaire responses indicate about $7 \%$ are of precedential value. Qucstionnaire, supra note 60, question 26.

${ }^{82}$ See text at note 67 , supra. Note that the use of available research tools continues at a rate roughly comparable to that proportion of cases in which the staff attorneys find their experience inadequate for preparation of no-action responses.
} 
has grown worse, when the prognosis was that it would improve, sale may be authorized - at least, where no substantial distribution is involved. Similarly, claims of changed circumstances resulting from termination of employment are often rejected. But a recent elaboration of that position resulted in the conclusion that if the applicant can support his claim with a showing that he had a written, unqualified employment contract for a specific term, he may be successful.

While all of these applications of the "change of circumstances" concept may have been affected by the presence of other "discretionary" considerations, such concrete interpretive examples are helpful to staff counsel precisely because they indicate the quality of the "change" currently viewed as sufficient by the Assistant Chief Counsel. And probably for that reason, the more important research tools relied upon by the staff counsel are their own copies of previous no-action letters and consultation with their colleagues. ${ }^{83}$

The effect of discretionary considerations upon ostensible "interpretations" is not to be discounted, however. A good example is found in the no-action matter considered by the Commission in Appendix B, paragraph C, and reported on a summary card. The summary card reflecting this action is marked "card only" because it is considered too unique-as a "change of circumstance" matter-to be included in the summaries distributed monthly to the staff counsel. The card provides an interpretation of the Commission decision which appears to demonstrate that the Commission routinely found no "changes" of circumstance that could not have been anticipated by the stockholder at the time of his purchase. But the card also recognizes at least one of the typical "discretionary" types of considerations that affect judgment in noting that the applicant's investment intent was compromised by the fact that he had made earlier repeated attempts to obtain a no-action letter. Furthermore, yet another "discretionary" consideration is found in examining the staff's supporting memorandum to the Commission, though the card indicates nothing about it. That memorandum shows that one of the applicants had been counsel for the president of the issuer and that he was currently under investigation and was thought to have been aware of the president's illegal activities. On that account, one of the Regional Offices had indicated that, under the circumstances, a no-action letter should not be granted. While it is uncertain what effect such additional considerations may have had on the outcome in this instance, availability of that information is helpful to a full appraisal of the Commission action in denying the application, and in that sense is a part of the "law" of the case.

Another aspect of the file of interpretive summaries which may render it unreliable as a basis for determining current interpretive positions is the fact that it includes an historical accumulation of cards reflecting positions taken at various times in the past, many of which may have been superseded by new positions also

\footnotetext{
${ }^{83}$ See note 66, stupra, and accompanying text.
} 
summarized in the cards. Informed researchers approach the cards with caution, frequently consulting one of the Assistants on apparent conflicts of position. That movement and conflict, however, do not diminish the status of no-action and interpretive positions as law; as with most legal sources, it merely requires thorough research to discern current positions and to resolve conflicting positions.

Finally, the inadequacy of many no-action letters as guides to interpretation is illustrated by comparing the no-action matters summarized in Appendix B, paragraph F: the staff simply offers no explanation for conflicting results in circumstances that appear substantially identical.

\section{VIII}

\section{The Role of Discretion}

As suggested above, the body of law found in the staff and Commission interpretive positions may be heavily influenced by various discretionary considerations that are brought to bear on specific no-action determinations. Those discretionary factors, together with the ad hoc nature of many "fact" determinations, have created a body of interpretive law in which "uncertainty and divergence of practice presently prevail to an unacceptable degree." ${ }^{\text {" }} 4$

While many discretionary considerations undoubtedly contribute to the uncertainty, others reflect staff efforts to provide means of protecting investors within a clumsy statutory and interpretive structure. Many of the concepts and distinctions required by currently-accepted interpretations of the 1933 Act have no real relevance to the protection of investors. The Disclosure Study commented:

The most casual inquiry into the effects of prevailing interpretative pattern discloses its grave shortcomings.... Sale without registration may turn on events wholly unconnected with the needs of investors....

An obvious question may be asked: in what possible way is ... "change of circumstances" relevant to the needs of public investors, so as to justify the sale of ... shares without appropriate disclosure? The easy answer to the question is "none."

In application, the present "fungibility concept" bears little relationship to the needs of investors for disclosure. It has never been formalized as a Commission rule or interpretative release, and hence introduces an additional element of uncertainty into an already clouded situation. ${ }^{85}$

It is apparent from the Disclosure Study discussion of these problems that many interpretive positions were taken and many discretionary factors taken into account, in order to prevent the formal structure of registration from choking off legitimate

\footnotetext{
84 Disclostre Study at 152.

${ }^{85}$ Disclosure STUdY at I55-56, I70, and I74.
} 
securities transactions intended to be exempted from the Act. The framework of subjective "ultimate fact" judgments provided the flexibility necessary to reach doubtful distributions, while permitting sales which appeared to be prompted by the financial needs of an innocent shareholder. But focusing on such subjective considerations often made confident judgment impossible precisely because theory focussed upon shareholder's motivations.

It is little wonder that under such circumstances, often involving a determination which might as well be decided by a flip of the coin, various other factors more obviously pertinent to the protection of shareholders should be taken into account. Many of those factors, mentioned at various times in discussion with staff personnel, were listed in responses to the questionnaire submitted to staff attorneys together with appraisals of their relative importance. The frequency with which such discretionary considerations were instrumental in decision is reported to be between 37 and and 45 per cent. ${ }^{36}$

There have been occasional suggestions that political factors play a large role in obtaining a favorable no-action response from the staff or Commission. And in at least one instance, available records seem to reflect "political" considerations. (See Appendix B, paragraph B.) But a careful analysis of many cases in which congressmen made written "status" inquiries with the Commission failed to demonstrate any substantial effect, except possibly a more prompt review of the matter and the preparation of an explanatory memorandum for the congressman.

Undoubtedly the most signifiant "discretionary" factor that plays a role in the outcome of no-action requests is the pendency of an investigation or an enforcement proceeding. Where a Regional Office or the Division of Trading and Markets indicates that a "hold" should be placed on no-action letters concerning stock of a particular issuer, a no-action request ordinarily will be met by a simple uncommunicative rejection. That practice seems often to be followed regardless of whether the immediate applicant appears to be involved in the potential proceedings. ${ }^{87}$ And it also seems that the staff is much more reluctant to authorize a no-action position for the benefit of a stockholder who has previously been found to be a securities violator.

Various other "discretionary" considerations which appear to play a part in decision reflect a desire to assure protection of the investor. Thus, particularly in close cases, the staff is more likely to look favorably on proposed sales of stock of a reporting company, or of the same class as that recently registered by the issuer, or sales which are within the ordinary trading volume of the stock in question. A variety of other discretionary considerations and their effect upon particular noaction requests are summarized in Appendix $B$.

\footnotetext{
${ }^{80}$ Questionnaire, supra note 6o, questions 30 and 14.

${ }^{87}$ See SEC "No-Action" Letters: Some Problems and Suggested Approaches, 7I CorUM. L. REv. I256, I270 (r97I).
} 
IX

\section{Conclusions and Recommendattons}

The no-action process as administered by the Division of Corporation Finance appears to be a sophisticated and effective system of providing informed and specific staff advice under active agency supervision. The basic conclusion of the Task Force On Legal Services and Procedure, Second Hoover Commission, appears to remain sound:

By practice and precedent, letters of advice and staff opinions are given limited validity ... [ by several agencies.] This excellent practice in administrative procedure has been most effectively used by the Securities and Exchange Commission, which issues several thousand such opinion letters annually .... The satisfactory experience of agencies which have ... followed the practice . . . suggests the advisability of a more general use of the advisory opinion by all agencies of the executive branch. 88

That accolade is justly cited with pride by Division personnel; and the accessibility and pragmatism of Division personnel, as reflected in the no-action process, is an outstanding example of an agency making government work effectively within the inevitably rigid confines of governing statutes. By exercising discretion to modify statutory rigidity and grant advisory assurance concerning enforcement intentions, the staff and Commission enable businessmen, in compliance with law, to execute legitimate securities transactions, while restraining transactions that may appear to offend the basic policy objectives of the I933 Act. But as the demand for advisory assistance grew, the emphasis on accessability and service to the industry began to overshadow the major objectives of the advisory processes.

The major objectives of the no-action advisory processes are set forth as follows in a Division memorandum:

The no-action letter procedure is used to assist persons to comply with the law in prospective transactions, to discourage unlawful transactions, and to assist in effectuating transactions that do not appear to be contrary to the intent of the statutes and rules. ${ }^{80}$

To this statement of objectives should be added the further objectives of "advising the staff in advance of activities that might be questionable," flow of information about financial and regulatory problems to assist the staff and Commission in developing, elaborating, and testing concepts and policies for current and future application.

The former policy of granting advisory clearances for specific transactions, in-

\footnotetext{
${ }^{88}$ Commisston On Organtzation Of The Executive Branch of the Government, Task Fonce Report on Legal Services and Procedure i89-9o (1955).

${ }^{89}$ Staff Memorandum to Warner W. Gardner, in REPORT, supra note 3, app. E at 2.

${ }^{\circ 0}$ Id.
} 
cluding a mass of routine transactions, appeared to operate on the implicit assumption that the best way to "assist persons to comply with the law in prospective transactions" was to run a clearinghouse for those transactions. That "clearinghouse" concept of the staff's advisory role consumed the time of some of the best-informed and most experienced attorneys in the Division of Corporation Finance and seriously interfered with their effectiveness in exploring new regulatory problems and developing sound interpretative positions and rules. While experience with some problems presented for advisory assistance can add to the staff's insight, the bulk of the noaction problems heretofore considered by the staff involved routine questions, unrewarding for development of policies or interpretations.

Recognizing that its objectives will be better served by a broadened public understanding of staff and Commission interpretations and policies, the Commission has sought, by Rule 144, to clarify the restrictions on secondary sales ${ }^{91}$ and has made publicly available its no-action and interpretive letters. ${ }^{92}$ Some interpretative problems in the application of Rule 144 will remain, of course; and there will be continuing requests for no-action letters in areas beyond the scope of the Rule. ${ }^{93}$ Nevertheless, these developments substantially expand public access to Commission policies and interpretations, while promising the staff a reduced burden of no-action requests. Additional Commission action along the lines begun in the release announcing Rule I44 could further reduce the burden of routine no-action or interpretative letters, leaving the staff more time for considered responses to inquiries presenting new or unique fact situations or interpretative problems. In order to derive maximum benefit from the public availability of no-action requests and responses, the Commission should encourage the staff to include in the public materials an adequate statement of facts and reasons. ${ }^{94}$ Where inquiries present matters fully covered by available interpretative materials, the staff should be encouraged to respond with a form letter or to decline any substantive response. And where continued administration of routine no-action requests is prompted by doubt about the reliability of the advice of private counsel, ${ }^{95}$ the Commission should develop and adopt rules of

\footnotetext{
${ }^{01}$ Release 5223 , supra note 6.

${ }^{92}$ Release 5098, sutpra note 48 . Provision has not yet been made to comply with the recommendation of the Report that public availability should extend to agency minutes and monthly interpretative summaries, interpretative staff memoranda "and all such statements by the staff which are of significant importance as a guide to interpretation. . ." REPORT, supra note 3 at 490 . But the importance of making available systematic statements of the staff's interpretive positions has again been emphasized in the recent study of enforcement policy instituted by the Commission. SEC, REPORT OF THE Advisory COMMITTEE on Enforcement Policies and Practices, at I7 (x972).

${ }^{13}$. Although the bulk of no-action letters relate to questions that Rule I44 attempts to resolve, examination of representative samples of the summaries of interpretations distributed monthly among the staff of the Division indicates that more than half of the no-action letters summarized deal with other problems.

it Inclusion of a statement of facts and reasons will also provide the applicant with an understanding of the factual and legal issues posed by his request, which is not assured by the existing procedures for processing no-action requests. See pages $\mathrm{II3}^{-14}$, supra. Where additional understanding suggests the pertinence of additional available facts, the applicant can request reconsideration.

${ }^{\circ C}$ See note 47 , supra and accompanying text.
} 
practice which will permit greater reliance on counsel by discouraging rendition of opinions on the basis of inadequate legal or factual investigation or in disregard of available interpretative positions.

The no-action process has been administered by the SEC staff with an unnecessarily broad conception of its discretionary power to grant or deny clearance. While the area of broadest discretion will be significantly narrowed by Rule I44, a more fundamental approach to the problem of unnecessary discretion is required. The key to that approach is adoption of a new policy respecting public disclosure of the agency's operating interpretations, standards, and policies. That new policy should assure the public availability of those positions, at least on a tentative basis, when they are first applied in no-action or other informal proceedings, rather than awaiting definitive development and formal pronouncement. It should encourage public statements of those operating interpretations, standards, and policies in as much generality as their current and projected applications permit, going well beyond conclusory "no-action" determinations wherever possible." Where general statements are not feasible, hypotheticals may be used to illustrate the application of narrower interpretative positions. ${ }^{98}$ And where discretionary factors are commonly considered in ameliorating or stiffening the informal application of estab. lished interpretations, standards, or policies, a list of those factors should be made publicly available with a general explanation of their pertinence to the informal determination and, where feasible, of their specific application.

Obviously, these recommendations raise issues about the control of discretion which go well beyond the no-action process. How much room should there be for discretionary staff judgments to temper the rigid limitations of law and established interpretations? Should that discretion be exercised openly with full public disclosure and the attendant risk of compromising the authority or enforceability of the law? ${ }^{97}$ Should it be exercised in secret with the attendant risks of discriminatory and abusive manipulation of power? Will open exercise of discretion produce demands for consistency which reduce the administrator's willingness to exercise needed and available discretion? Are there legal or administrative devices which will permit administrators to maintain the authority and enforceability of the law despite open exercise of discretion?

The recommendation that the thinking of the staff and Commission respecting interpretations, standards, policies, or discretionary factors be fully disclosed does not imply any illusions about the difficulty of the above questions. Rather, it is based on the assumption that pragmatic resolution of these problems can be achieved and that full disclosure will produce greater compliance benefits, as well as greater

\footnotetext{
${ }^{\circ 0}$ K. Davis, Discrettonary Justice 62 (1969).

${ }^{97}$ For a statement of the need for a wide and uncertain range of administrative discretion in order to prevent "imaginative fraud" in the field of securities regulation "where publicly stated rules are one of the instruments of fraud . ..." see Mason, Administrative Law-Reality or Red Tape, 4o Rzv. Jun. U.P.R. 9 I ( $(97 \mathrm{r}$ ).
} 
fairness, than retention of an uncertain and unneeded range of discretion. As Professor Davis has demonstrated, we have too long operated on the opposite assumption.

\section{APPENDIX A: TYPICAL FORMATS OF SEC NO-ACTION RESPONSES}

"Based on the facts presented, we are not able to conclude that the sale of shares of - Corporation to the public at this time would be exempt from the registration requirements of the Securities Act of 1933."

"On the basis of the facts submitted, this Division will not recommend any action to the Commission, if —_ sells the — shares of —_ Corporation without compliance with the registration requirements of the Securities Act of I933."

"Based on the facts presented, this Division is unable to conclude that the — shares of Corporation may be sold by — without complying with the registration requirements of the Securities Act of 1933."

"Based upon the facts presented and particularly in view of the short holding period by the present owner and preceding owner, and the medical circumstances that arose before the purchase of the shares, this Division is unable to conclude that the shares which your client owns may be sold without compliance with the registration requirements of the Securities Act of 1933, as amended, or Regulation A, if available."

"Based on the facts presented, including counsel's opinion that Mr. _- 's continued need for medical attention is a new and unanticipated circumstance, although an exemption from the registration requirements of the Securities Act of I933 is not free from doubt, in view of the small amount of your client's holdings, this Division will not recommend any action to the Commission if the — shares of Corporation stock are sold without compliance with such requirements."

"Based on the facts presented, this Division will not recommend any action to the Commission if your client sells the shares in question without prior compliance with the registration requirements of the Securities Act of 1933 in reliance upon your opinion as counsel that the proposed transaction is exempt therefrom."

"Based upon the above facts, as more fully set forth in your (counsel's) letter, we are unable to concur in your opinion. Accordingly, no public offer or sale of the shares of X Company by Mr. B should be made without compliance with the registration requirements of the Securities Act of 1933 ." 


\section{APPENDIX B: SUMMARY OF DISCRETIONARY FACTORS CONSIDERED IN PARTICULAR NO-ACTION MATTERS}

The following summaries reflect discretionary considerations taken into account by the staff or Commission in making particular no-action determinations. It is not feasible to provide detailed explanations of the particular cases, but detailed statements by the staff or Commission explaining the particular determinations are set forth in Appendices L-I through L-Io to the Report, supra note 3. Those statements are relied upon and cited here as the source of the particular case in which the various discretionary factors were considered.

\section{A. Refusal of No-Action Position Where Administrative or Enforcement Pro- ceedings Are Pending (Appendix L-2)}

In this instance, the applicant had held the stock in question for what would ordinarily be an adequate "holding period" before seeking permission to sell. With respect to the interpretation by which he sought to justify his sale, the Division expressly agreed that his "conclusion of law is correct." But because the Division of Trading and Markets suggested that the issuing company may be merely a shell, that some of the promoters of the company had been involved in prior securities violations, and that the applicant had served the company as counsel, a no-action letter was denied. In this case, after receiving three responses from the staff that were totally uncommunicative about the reasons for the denial, the applicant threatened to make a sale of a portion of his holdings and to invite Commission enforcement personnel to witness the sale. (See also the staff memorandum in Appendix L-r, Report, supra note 3 , at n. 3 , indicating that a no-action position was denied in a previous matter because "the Division of Trading and Markets was at that time conducting an informal market quiz to determine the causes for a price rise in the company's stock ...."

\section{B. Extensive Losses by Large Employer, With Resulting Prospect of Reducing Employment and Intervention by Commerce Department (Appendices L-3 and $L_{-4}$ )}

This involves comparison of two similar matters, which should be considered together. The first matter demonstrates a routine denial of a request based upon a claimed "change of circumstances" arising out of pressing financial and business circumstances. The staff generally views such circumstances as ordinary financial risks which the stockholder should have anticipated.

Similar considerations might have produced a similar result in the second matter (Appendix L-4). Indeed, the staff memorandum so recommends because an accident and engineering difficulties put the applicant behind schedule in developing a prototype and created his claimed "change of circumstances" requiring additional capital. In the staff's view, those contingencies would reasonably be expected as a 
part of the risks of developing a prototype. But the Commission was obviously swayed by the extent of the losses involved, by the possible increase in local unemployment that would result from discharge of the applicant's many employees, or by the intervention of administration officials pressing the latter argument. This no-action matter does not appear to have been made the subject of an interpretive summary.

\section{C. "Investment Intent" Compromised by Premature Attempts to Obtain No- Action Letter (Appendix L-5)}

In this matter, the interpretive summary card expressly asserts and relies on the view that early and repeated attempts to obtain a no-action letter may compromise any claim of original investment intent. Further, though not reflected on the summary, it demonstrates that enforcement considerations may play a part in decisionin this case, the pendency of an investigation of the issuer and the applicant's possible involvement in the matter under investigation. For that reason, it leaves some doubt whether the interpretive summary reflects all of the reasons for the result.

D. Refusal of No-Action Position Based On Internally-Adopted Rules (Appendices LrI and L-8)

One no-action request (in Appendix L-I) proposes a sale of stock acquired on warrants by an underwriter of an issuer's earlier registered distribution. Although alternative reasons for denial are offered, one substantial explanation appears to be the staff's development of a presumption that warrants received by underwriters in connection with an earlier distribution are invariably taken for sale and not for investment. Here, the underwriter-applicant appears to have held the stock for more than three years, after holding the warrants for a year and a half-more than adequate to satisfy the usual holding period applied in other no-action cases. The staff, however, contends that where warrants have been issued as additional underwriting compensation, stock acquired on the exercise of those warrants must be presumed to have been acquired for sale rather than investment.

A similar hard-and-fast but unpublished rule is reflected in Commission action on the second matter (in Appendix L-8). This case involved an apparently legitimate claim on the part of a former member of a controlling family group that family friction, and his resulting expulsion from any policy-making position in the company, constituted a "change of circumstances" which could justify sale. Though such claims had been approved not infrequently, the Commission here disapproves because of a policy decision to deny no-action letters to all members of controlling family groups.

\section{E. Conditional Grants of No-Action Letters (Appendix L-IO)}

Although the practice is not common, the Commission will occasionally extract a condition as the basis for granting a no-action letter. In this instance, the Com- 
mission approved a no-action position on the condition that the applicant agree not to buy a certain class of shares in the future-presumably because of the applicant's affliations with those companies. In another instance, a variation on this theme, the Commission "concluded that, under the special facts here involved, the staff might take a 'no-action' position after the expiration of two years" from the date on which the applicant had acquired the stock in question-an authorization to the staff somewhat at odds with the theory that investment intent is proved after an appropriate holding period. And in a third instance, the Commission rejected a request to sell 692,050 shares, constituting $22.6 \%$ of the issuer's outstanding shares, but indicated that if the applicant and his counsel "of their own volition withdrew that request and made a new request relating to roo,00o shares, it would grant the latter request." (The latter two examples are drawn from Commission minutes and staff memoranda made available to the author but not a matter of public record.)

\section{F. Absence of Any Apparent Explanation For Diverse Results in Similar Cases (Appendices $L-6$ and $L-7$ )}

In these matters, one applicant is permitted to sell 225,000 shares representing $14.5 \%$ of the issuer's outstanding stock, the last 75,000 shares of which were acquired I $4 \frac{1}{2}$ months earlier; but the other applicant is denied the right to sell 5,006 shares (presumably less than $14.5 \%$ of outstanding) which were acquired in an exchange effective approximately 16 months earlier. Both applications appear to be based upon a claim of unanticipated discharge from employment, and neither staff letter includes any explanatory rationale. While some theories might be elaborated to explain the difference, no adequate explanation appears on the face of the letters. 